\title{
Foreign Booms, Domestic Busts: The Global Dimension of Banking Crises ${ }^{\text {t3 }}$
}

\author{
Ambrogio Cesa-Bianchi ${ }^{\dagger} \quad$ Fernando Eguren Martin ${ }^{\ddagger}$ \\ Gregory Thwaites ${ }^{\S}$
}

January 24, 2017

\begin{abstract}
This paper provides novel empirical evidence showing that foreign financial developments are a powerful predictor of domestic banking crises. Using a new data set for 38 advanced and emerging economies over 1970-2011, we show that credit growth in the rest of the world has a large positive effect on the probability of banking crises taking place at home, even when controlling for domestic credit growth. Our results suggest that this effect is larger for financially open economies, and is consistent with transmission via cross-border capital flows and market sentiment. Direct contagion from foreign crises plays an important role, but does not account for the whole effect.
\end{abstract}

Keywords: Financial Crises, Global Credit Cycle, Banking, Financial Stability, Sentiment.

JEL Codes: E32, E44, E52, G01.

\footnotetext{
We would like to thank Eugenio Cerutti, Matthieu Chavaz, Stijn Claessens, Jean Imbs, Oscar Jorda, Sebnem Kalemli-Ozcan, Giovanni Lombardo, Carmen Reinhart, Ilhyock Shim, Alan Taylor, James Yetman, and participants at the "UNSW/ADB International Conference on Financial Cycles, Systemic Risk, Interconnectedness, and Policy Options for Resilience", and at seminars at the Bank of England, Reserve Bank of Australia, BIS Asia Office, and BIS headquarters for helpful comments and suggestions. The views expressed in this paper are solely those of the authors and should not be taken to represent those of the Bank of England.

Online appendix available at https://sites.google.com/site/ambropo/CET_Crises_OnlineAppendix.pdf.

${ }^{\dagger}$ Bank of England and CfM. Email: ambrogio.cesa-bianchi@bankofengland.co.uk.

${ }^{\ddagger}$ Bank of England. Email: fernando.egurenmartin@bankofengland.co.uk.

$\S$ Bank of England and CfM. Email: gregory.thwaites@bankofengland.co.uk.
} 


\section{Introduction}

It is well established that financial crises are often "credit booms gone bust" (Eichengreen and Mitchener, 2003, Schularick and Taylor, 2012). But this is not always the case. Why, for example, did Japan and Germany suffer financial crises, in the late 1990s and 2008 respectively, when credit growth had been subdued in both places? Why did Ireland suffer a crisis after a credit boom in 2008, but not in 2000 when credit had been growing even more quickly?

This paper documents the crucial role of global financial conditions and, in particular, of credit growth abroad, in determining the risk of a domestic banking crisis. While it is well established that credit growth and banking crises are synchronized across countries (Laeven and Valencia, 2013, Reinhart and Rogoff, 2009, Claessens et al., 2011, Mendoza and Terrones, 2014), the literature has typically focused on domestic determinants of banking crises and has singled out high domestic credit growth as the single best predictor (Schularick and Taylor, 2012, Jorda et al., 2011).

In this paper we depart from this domestic focus. Using a new dataset linking credit growth and financial crises for 38 advanced and emerging economies over 1970-2011, we study the role of foreign credit growth (that is, domestic credit growth in the rest of the world) in affecting the probability of experiencing domestic banking crises. Our results provide novel empirical evidence demonstrating a systematic link between global credit growth and the subsequent occurrence of domestic banking crises, conditional on domestic credit. This link improves dramatically the predictive ability of banking crises models that only rely on domestic indicators.

Our main findings are as follows. First, we provide some novel evidence on a stylized fact that is central to our analysis: both credit growth and the occurrence of crises are synchronized across countries. We start by showing that the empirical distribution of the number of banking crises at any one time has fatter tails than a binomial distribution, i.e. the distribution they would follow if crises were independently distributed across countries. We formally test for this correlation with a 'stable correlation binomial model' (Witt, 2014), a generalization of the binomial distribution that allows for a positive correlation between any two pairs of trials. Our estimates show that such correlation is positive and statistically different from zero in two different data sets, formalizing the informal notion that banking crises display a positive degree of cross-sectional dependence.

We also show that real domestic credit growth is correlated across countries, and that this synchronization has increased over time. We compute different metrics to assess the degree 
of international comovement of real domestic credit growth in our data set, which includes a larger set of countries relative to what has typically been considered in the previous literature. We find that a single factor (extracted with a simple principal component analysis) can explain up to 50 percent of the variance of countries' real domestic credit growth in recent times; and that the average correlation between country-specific credit growth and world credit growth has increased over time.

Second, we show that foreign credit can substantially increase the predictive power of models that only rely on domestic credit as an explanatory variable for the occurrence of banking crises. ${ }^{1}$ Specifically, we find that foreign credit growth is a significant predictor of domestic banking crises, even when controlling for domestic credit growth. This is shown to be true for our new dataset as well as for the longer, narrower panel in Schularick and Taylor (2012), which covers 14 advanced countries over the 1870-2008 period.

Third, and finally, we explore the role played by openness to international trade and financial transactions with non-residents, as well as by a number of other covariates suggested by the literature, to help distinguish between the potential economic mechanisms that drive our findings. We find that the role played by foreign credit growth is more important for financially open countries, but not for countries more open to trade. This suggests that the channel of transmission behind our findings is itself financial, rather than going through the effect of foreign credit on foreign real activity and hence demand for domestic goods and services via trade.

To shed further light on the channels that mediate this effect, we explore how the inclusion of additional covariates affects our results. We demonstrate a statistically significant association between cross-border portfolio inflows and subsequent domestic banking crises, but cross-border bank lending (to either domestic banks or non-banks) does not have a significant effect. We also find that a reduction in US short-term interest rates and in global risk aversion, as proxied by a fall in the VIX index (as emphasized inter alia by Rey, 2013, Bekaert and Hoerova, 2014), an increase in the leverage of US broker-dealers (Bruno and Shin, 2015), and a compression in the level of US corporate bond spreads (Lopez-Salido et al., 2016), all portend an increased risk of a domestic banking crisis further down the line. Finally, we also find that the occurrence of crises abroad raises the probability of a crisis at home, but that foreign credit growth remains a robust predictor over and above this, suggesting that while contagion may play a role, it cannot be the whole story.

\footnotetext{
${ }^{1}$ Throughout the paper we refer to the average of domestic credit growth in the rest of the world as 'foreign' credit. It is worth noting that this indicator is constructed from domestic credit growth in all countries in the sample but the country of interest, without any cross-border component.
} 
We interpret our evidence as suggesting that domestic financial stability is at the mercy of exogenous push shocks and broader swings in global sentiment, which can affect the probability of domestic banking crises over and above their relationship with both domestic credit growth and the realization of banking crises abroad. Global risk sentiment can be captured with variety of price- and quantity-based proxies, of which foreign credit growth is a prominent example.

Related literature. This paper is related to three broad strands of literature. First, it relates to a growing literature on the time series and cross-sectional properties of financial crises and their determinants. As such, this paper is first and foremost related to the literature on the classification and description of financial crises. See, among others, Caprio and Klingebiel (1996), Caprio and Klingebiel (2002), Laeven and Valencia (2013), Bordo et al. (2001), Reinhart and Rogoff (2009) and Qian et al. (2011).

A second strand relates to the determinants of financial crises. More specifically, our work is closely related to papers that investigate whether there is systematic evidence of credit growth-induced financial instability, as motivated by theoretical work on debt-driven booms and busts, such as Fisher (1933), Minsky (1986), and Kindleberger (1978). ${ }^{2}$ In a series of recent papers, Schularick and Taylor (2012) (ST hereafter) and Jorda et al. (2011) have revived this literature using a long-run data set for advanced economies, and relying on tools from the theory of binary classification and signal detection (see Jorda and Taylor, 2011). We are most directly related to these latter papers. Relative to them we consider a shorter, but wider panel data set and, most importantly, we consider the role of foreign credit as an explanatory variable for domestic banking crises.

The third strand has investigated the link between global variables and domestic financial stability (see, for example, Frankel and Rose, 1996). In two related studies, Alessi and Detken (2011) and Duca and Peltonen (2013) use global variables as early warning indicators for costly asset price boom/bust cycles and periods of financial stress (as measured by a synthetic index computed using financial markets data). In our paper we use a similar insight but relate it to the synchronicity of banking crises and apply it to the literature of binary classification and prediction of crises started with the seminal paper by ST. Moreover, relative to those studies, we expand the number of countries under consideration and/or consider a longer sample period, and we explore additional dimensions not considered by them (such as financial conditions in centre countries and, importantly, the role of countries'

\footnotetext{
${ }^{2}$ Some early studies in this literature are Reinhart and Kaminsky (1999), Eichengreen and Mitchener (2003), Borio and Lowe (2002a), Borio and Lowe (2002b), Borio and White (2003), Borio and Drehmann (2009) and Gourinchas and Obstfeld (2012).
} 
financial and trade openness in influencing the effect of global variables on domestic financial stability).

The paper is structured as follows. In Section 2 we present stylized facts on the international synchronization of banking crises and domestic credit growth. In Section 3, we set out to quantify the links between domestic banking crises and foreign credit growth, exploring the relevance of financial and trade openness. In Section 4 we inspect the mechanisms behind our main results. Section 5 contains extensive robustness checks. Finally, Section 6 concludes.

\section{Data \& Some New Stylized Facts}

In this section we report some novel stylized facts on the international dimensions of banking crises and credit growth. Specifically, we show that (i) there is a statistically significant crosscountry dependence in the occurrence of banking crises and (ii) real domestic credit growth is highly synchronized across countries, i.e. there is a global credit cycle. Before turning to the empirical analysis we briefly describe the data we use.

\subsection{Data}

Banking crises are rare events. The study of their determinants therefore requires either a long time series or a large cross-section of data. In a recent influential paper on this topic, ST opt for the former, constructing a dataset of 14 advanced economies over a long time period from 1870 to 2008. In this paper we opt for the latter, extending the cross-section of countries considered, at the cost of having to restrict the study to a shorter time period. This seems particularly suitable when studying the effect of 'global' variables that are computed exploiting the cross-sectional dimension (such as common factors or principal components). In order to do so, we compile a data set that merges the banking crisis series of Laeven and Valencia (2013) (LV hereafter) with the series on credit constructed by the BIS. These are well known and readily available data sets. However, we use them in a novel fashion since - to the best of our knowledge - they have not been used to answer the questions we ask in this paper.

LV put together a comprehensive database of systemic banking crises in 162 countries over the 1970-2011 period. Their methodology to date crises is based on a range of indicators, including bank runs, banking system losses, bank liquidations and banking policy interventions. The resulting database is now well-established and widely used in the literature (see, 
for example, Acharya et al., 2014, Broner et al., 2013, Ghosh et al., 2015). The credit data that we use comes from the BIS, who compile credit stocks for 38 countries at quarterly frequency beginning at different points in time. ${ }^{34}$ To keep consistency with the previous literature we consider total credit from domestic banks to the domestic private non-financial sector. ${ }^{5}$ We deflate the data with each country's CPI to obtain a real index and we then compute growth rates.

The resulting dataset is an unbalanced panel of 38 countries at annual frequency over the 1970-2011 period. We report additional information about the sources of our data, the list of countries, and some summary statistics in Appendix A. Having a larger cross-section but a smaller time series dimension relative to ST has both advantages and disadvantages. On the one hand, our sample period beginning in 1970 is more homogeneous than the long period considered in ST. On the other hand, however, ST's sample of exclusively advanced countries is likely to be more homogeneous and less plagued by episodes of economic instability that were once typical of emerging markets. As Reinhart and Rogoff (2009) demonstrate, however, the antecedents and aftermath of banking crises in rich and emerging countries have a surprising amount in common. ${ }^{6}$

\subsection{Cross-country Dependence Of Banking Crises}

Banking crises tend to come in waves. This is clearly visible from a simple plot of the frequency of banking crises, reported in Figure 1. As in Reinhart and Rogoff (2009), Figure 1 plots a three-year moving average of the share of all countries experiencing banking crises using our data set (dashed line). For comparison, we also plot the frequency of banking crises computed using ST's data set (solid line). Figure 1 clearly shows that there are periods when many countries contemporaneously experience a banking crisis. ${ }^{7}$ This is particularly true in the early 1900s and, not surprisingly, during the recent global financial crisis.

\footnotetext{
${ }^{3}$ When merging the two datasets we convert the BIS data from quarterly into annual frequency by taking averages within the year. The results are unchanged when using end of year values.

${ }^{4}$ Domestic banks include both domestically headquartered banks and local affiliates of foreign banks. We cannot distinguish between the two due to data limitations, but work has been done in this respect (see, for example, Claessens and Horen, 2014).

${ }^{5}$ Alternatively, one could use total credit, as measured by the sum of domestically generated credit and cross-border credit.

${ }^{6}$ We nevertheless explore differences between advanced and emerging countries in Section 5 .

${ }^{7}$ Figure 1 depicts the proportion of countries in which a systemic banking crisis begins in a given year. This is different from Reinhart and Rogoff (2009), who plot the proportion of countries that are experiencing a systemic banking crisis in a given year. Although LV also provide data on the duration of banking crises, ST do not, and hence we stick to our definition for consistency.
} 


\section{Figure 1 Proportion Of Countries With Systemic Banking} CRISES

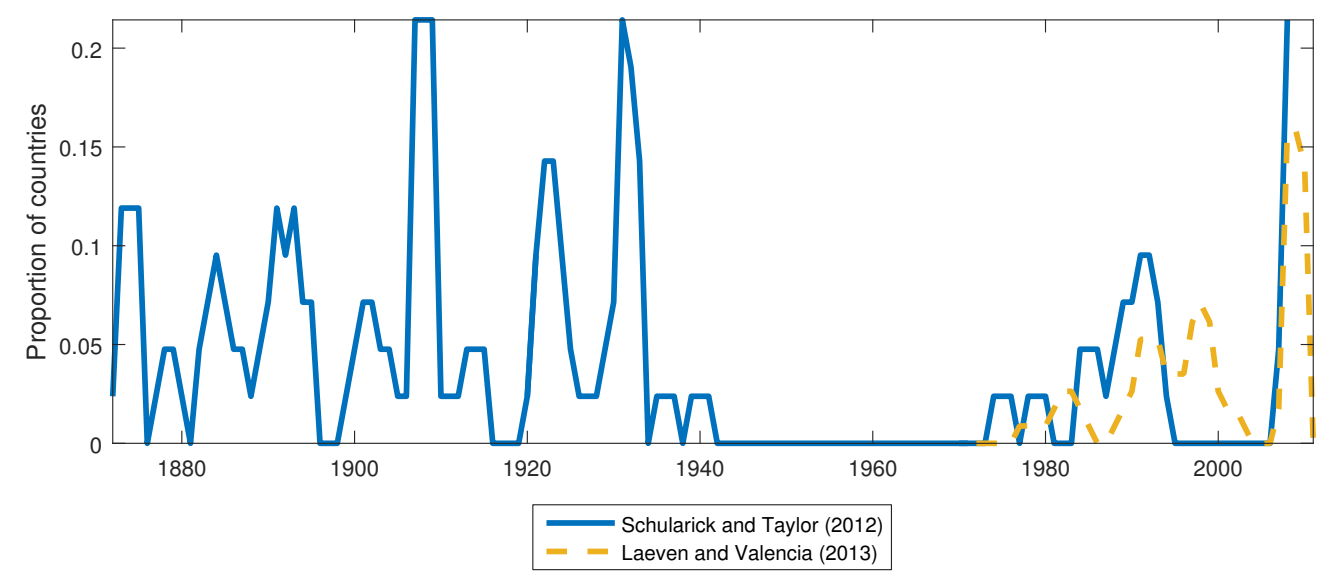

Note. Proportion of countries with (the start of) systemic banking crises over a long historical sample going from 1870 to 2008 using ST historical data set; and over the shorter period from 1970 to 2011 using LV data set. 3-year moving average as in Reinhart and Rogoff (2009).

While the simple non-parametric evidence reported in Figure 1 is striking, more formal evidence is required to back the statement that banking crises are correlated across countries. With this in mind, in this section we provide a parametric test of cross-country dependence of banking crises. Since the test we propose is novel, we perform it on both ST's and LV's data sets. First, note that if crises were independently distributed across countries with a time-invariant probability, then they would follow a binomial distribution. ${ }^{8}$ Panel A of Figure 2 shows the histogram of crises occurrence in ST's data set, alongside a binomial distribution with the same average crisis probability of 4 percent (solid line). ${ }^{9}$ It is clear from the chart that the empirical distribution of crisis has much fatter tails than the binomial distribution, indicating that crises are correlated.

For example, there are four instances in the sample in which five or more countries (out of a total of fourteen) experience a banking crisis. Given that ST data set spans sample 139 years, the frequency of such event is approximately 3 percent. Were crises independently distributed across countries with a fixed probability (equal to the average sample frequency), the frequency of such event (an instance in which five or more countries are experiencing a banking crisis simultaneously) would be 0.02 percent - two orders of magnitude lower.

\footnotetext{
${ }^{8}$ If the common unconditional probability of crisis varied over time, this would be logically indistinguishable from crises being correlated across countries.

${ }^{9}$ The y-axis is scaled with a concave function to better illustrate the difference in predicted probabilities between rare events.
} 
Even more starkly, the one instance in the sample of nine crises should occur once every 100 million years or so.

Figure 2 Empirical And Predicted Frequency Of BankING CRISES

(A) Schularick and Taylor (2012) Data

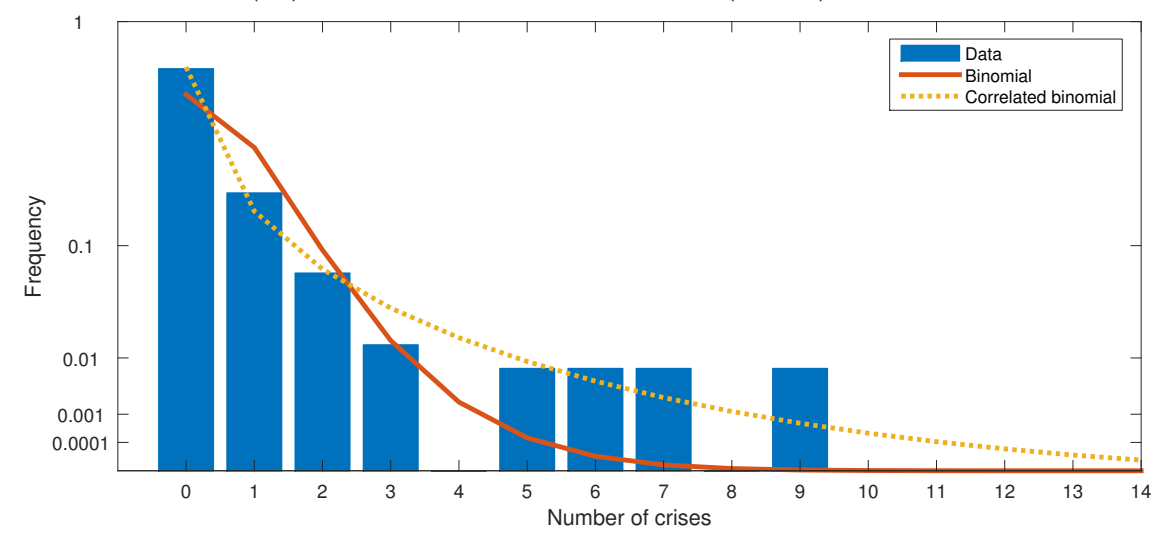

(B) Laeven and Valencia (2013) Data

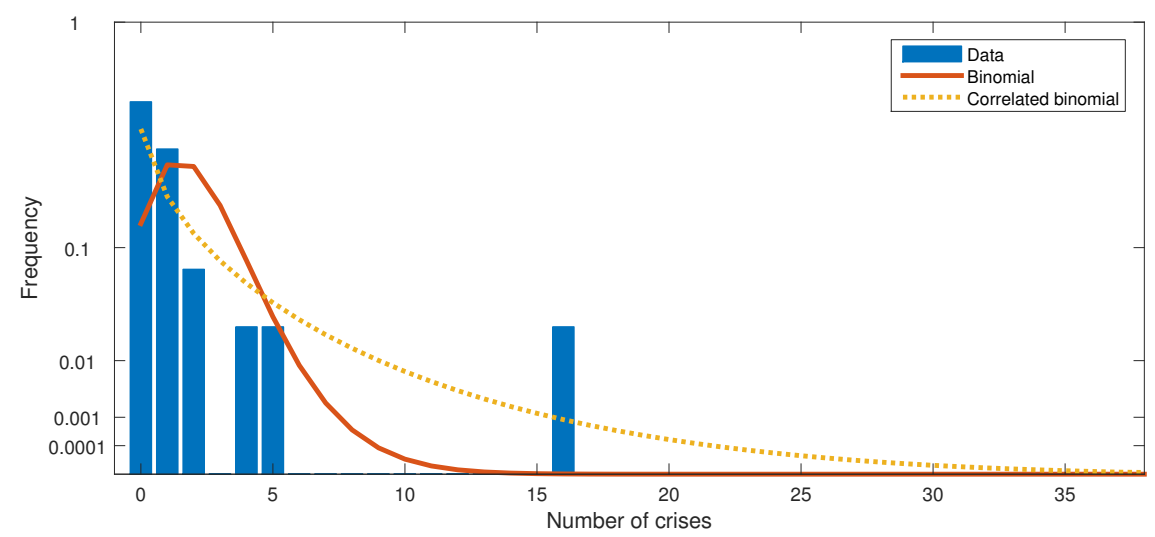

Note. Proportion of countries experiencing (the start of) systemic banking crises in the data (bars), predicted by a standard binomial distribution (solid line), and predicted by a correlated binomial distribution (dotted line). The data used is the original data from ST and LV in panels A and B, respectively.

We can parameterize and formally test for this correlation with a 'stable correlation binomial model' (Witt, 2014), a generalization of the binomial distribution in which the unconditional probability of any one country suffering a crisis is $p$ and the unconditional correlation between any two pairs of trials is $\rho$, such that the joint probability of any two countries simultaneously suffering from crises is $p^{2}+p(1-p) \rho$. We fit this model to the distribution of annual crisis events in ST's dataset and estimate its parameters by maximum 
likelihood. We find central estimates of $p$ and $\rho$ of 0.04 and 0.11 respectively.

The associated probability mass function is plotted in Panel A of Figure 2 (dotted line). Not surprisingly, the probability mass function of the correlated binomial model displays fatter tails relative to those of the standard binomial. We can then formally test the significance of $\rho$, i.e. the parameter governing the correlation of crises across countries. We use the standard trinity of classical tests applied to maximum likelihood estimators. The results imply that we can strongly reject the null hypothesis that the correlation between countries $(\rho)$ is zero: the p-values for the Wald, likelihood ratio and Lagrange multiplier tests are all well below the 1 percent significance level. We therefore conclude that there is strong statistical evidence that confirms the observation that financial crises display a cross-sectional dependence. $^{10}$

Results are similar when we use the data set of LV. Panel B of Figure 2 reports the histogram of crises occurrence in LV's data set, alongside a binomial distribution with the same average crisis probability (solid line). We fit the stable correlation binomial model and find central estimates of $p$ and $\rho$ of 0.05 and 0.08 respectively. As for ST's data set, also in this case we can strongly reject the null hypothesis that the correlation between countries $\rho$ is zero at the 1 percent confidence level.

\subsection{A Global Credit Cycle}

A well-known stylized fact is that credit growth tends to be correlated across major advanced economies, and that this correlation has increased over time (Claessens et al., 2011, Hirata et al., 2012, Aikman et al., 2015, Cerutti et al., 2014, Mendoza and Terrones, 2014). This section investigates the international comovement of real domestic credit growth from a global perspective, taking into account a larger set of countries that includes both emerging and advanced economies.

We compute two different metrics to assess the degree of international comovement of real domestic credit growth: (i) the share of the variance explained by the first principal component computed on the countries for which we have a complete coverage over the 19702015 sample; and (ii) an average cross-country correlation measure, computed at every point in time as the cross-country average of the correlation between each country's domestic credit growth and domestic credit growth in the rest of the world (measured as simple cross-sectional

\footnotetext{
${ }^{10}$ Note that these results are not affected by the presence of the recent global financial crisis in the sample. The sample frequency, binomial, and correlated binomial distributions for the sample 1870-2006 are reported in the Appendix in Figure B.1.
} 
averages). ${ }^{11}$ Finally, to analyze the evolution over time of such synchronization measures, we compute both measures on three different samples: the full 1970-2015 sample, and two sub-samples, namely 1970-1994 and 1995-2015.

\section{Figure 3 International Synchronization Of Credit GROWTH}

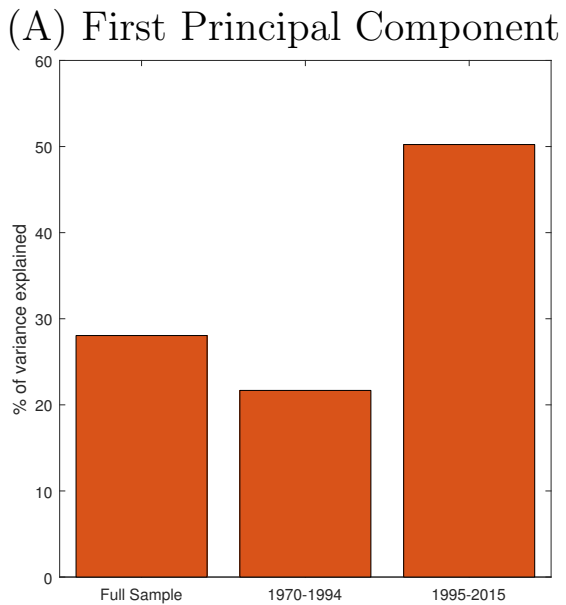

(B) Average Correlation

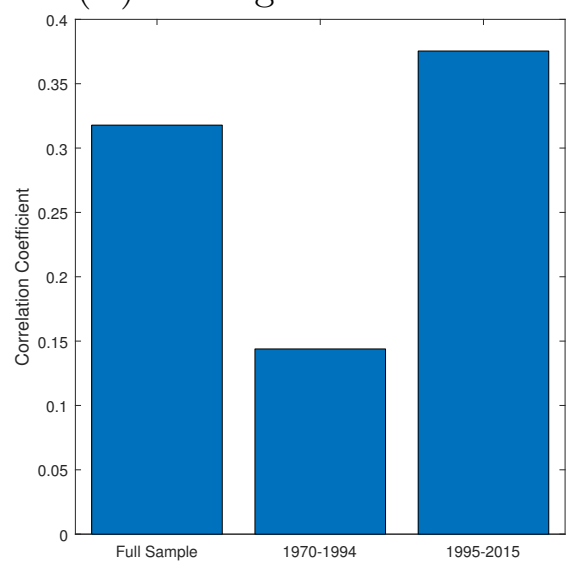

Note. Panel A reports the share of the variance of real domestic credit growth explained by the first principal component, obtained using a sample of 22 countries for which we have data covering the full 1970-2015 period. Panel B reports the cross-country average of the correlation between country $i$ 's credit growth and credit growth in the rest of the world, computed as the weighted average of credit growth the remaining $N-1$ countries (where $N=38$ ) over the the full sample.

Figure 3 reports our measures of synchronization. Panel A shows that a significant portion (around 30 percent) of the variance of countries' real domestic credit growth can be explained by the first principal component. ${ }^{12}$ This suggests that credit cycles are synchronized at the global level. The share of variance explained by the first principal component is in line with previous findings in the literature (Hirata et al., 2012). This is striking given the different sample used in this paper, that includes both advanced and emerging economies. ${ }^{13}$ In addition, Figure 3 clearly shows that real domestic credit growth has become more synchronized over time. The variance explained by the first principal component has increased from slightly

\footnotetext{
${ }^{11}$ Note here that in the case of balanced panels both approaches can be used and provide different measures of synchronization. But in the case of unbalanced panels, which is the type of panels we are considering here, the average correlation has the advantage that it can be applied to a larger number of countries.

${ }^{12}$ Figure B.2 in the Appendix shows that the eigenvalues in the scree plot decay quite fast, suggesting that there is an important common factor among the series.

${ }^{13}$ Cesa-Bianchi (2013) finds a similar pattern in the international synchronization of real house price returns.
} 
more than 20 percent in the pre-1995 period to about 50 percent in the post-1995 period. ${ }^{14}$

Panel B reports a measure of average cross-country correlation with global averages computed over the three sub-samples. The average cross-country correlation of real domestic credit growth with rest-of-the-world averages is just above 0.3. Again, this finding is consistent with those reported previously in the literature for other sample periods and/or just for advanced economies (e.g. Hirata et al., 2012, Cerutti et al., 2014). In line with the principal component analysis, the correlations also suggest that synchronization has increased over time. Note that this approach is completely silent as to the reasons why such a substantial share of the variance of international credit growth can be explained by common factors. ${ }^{15}$ But it clearly shows that real domestic credit growth can be highly correlated across countries and that such correlation has substantially increased over time.

\section{The Global Determinants Of Domestic Banking Crises}

This section of the paper assesses and quantifies the relevance of foreign credit growth for domestic financial stability and the role of economic openness in mediating its effects.

\subsection{The Role Of Foreign Credit}

Schularick and Taylor (2012) (and other authors after them) have established that domestic credit growth is a robust predictor of financial crisis. ST's study is the jumping-off point for the analysis in this section. They run panel Logit and linear probability regressions of banking crisis episodes on domestic credit growth and find highly significant time (year) fixed effects. ${ }^{16}$ This is consistent with the observation that banking crises tend to happen in waves and often afflict multiple countries simultaneously, as shown in the previous section. ST note the relevance of this finding but also warn of practical difficulties:

\section{"[...] if you happen to know this effect ex ante, you can use it to dramatically enhance your ability to predict crises [...] but is also not of very much practical}

\footnotetext{
${ }^{14}$ Note that this increase in synchronization over time (as well as the one reported below using the average cross-country correlations) is robust to excluding the global financial crisis from the sample period. See Figure B.3 in the Appendix.

${ }^{15}$ Much of the variance explained by the first principal component, in fact, may be accounted for by common factors in global GDP or global interest rates rather than common intrinsic 'credit' factors.

${ }^{16}$ See column (3) in Table 3 in Schularick and Taylor (2012), which we replicate in Table B.2 in the Appendix using our new database.
} 
import for out-of-sample forecasting, since such time effects are not known exante. Thus, from now on, given our focus on prediction, we study only models without time effects."

If it were possible to unearth what lies beneath this common global time component in the occurrence of banking crises, it would be possible to improve out-of-sample forecasting ability. ${ }^{17}$ In particular, the observations that (i) banking crises come in global waves and (ii) credit growth predicts financial crises naturally lead us to consider the role global credit conditions play in predicting domestic banking crises, over and above that of domestic credit. Given the proven importance of domestic credit growth for the occurrence of banking crises, one plausible conjecture is that credit growth in the rest of the world could also affect the probability of a banking crisis taking place at home.

Note that if crises tend to happen in waves solely because countries experience synchronized credit booms, then foreign credit would not help to predict domestic crises over and above domestic credit. However, it could also be the case that foreign credit growth has an independent role in explaining banking crises at home, either via the occurrence of crises abroad or even without the need of such events. There are various potential channels for this effect, including foreign exposures of the domestic banking sector, international asset price comovement, capital flows, direct crisis contagion, global shifts in risk aversion, and other real channels such as trade for example. We will assess these channels in detail in Section 4.

One way of testing for the hypothesis that foreign credit matters for the occurrence of banking crises at home is to add a measure of credit growth in the rest of the world to the regression used in ST. That is, we can estimate the following models:

$$
\begin{aligned}
p_{i t} & =b_{0}+\sum_{j=1}^{L} b_{1, j} \Delta C r e d_{i, t-j}+\sum_{j=1}^{L} b_{2, j} \Delta C r e d_{i, t-j}^{*}+e_{i t}, \\
\operatorname{logit}\left(p_{i t}\right) & =b_{0}+\sum_{j=1}^{L} b_{1, j} \Delta C r e d_{i, t-j}+\sum_{j=1}^{L} b_{2, j} \Delta C r e d_{i, t-j}^{*}+e_{i t},
\end{aligned}
$$

where $\operatorname{logit}\left(p_{i t}\right)=\ln \left(p_{i t} /\left(1-p_{i t}\right)\right)$ is the $\log$ of the odds ratio, $L$ is the maximum number of lags considered; $\Delta$ is the difference operator; $\Delta C e_{i t}$ is the log-difference of real credit in country $i$ as defined above; and $\Delta C r e d_{i t}^{*}$ is our $i$-specific measure of (log-differenced) real

\footnotetext{
${ }^{17}$ Note that, while we study the drivers of the global time component in banking crises, we do not perform out-of-sample forecasting exercises given the low frequency and short timespan of our data.
} 
credit in the rest of the world, defined as:

$$
\Delta \operatorname{Cred}_{i t}^{*}=\frac{\sum_{j=1}^{N} w_{j} \Delta C r e d_{j t}}{N-1} \quad j \neq i
$$

where $N$ is the total number of countries in the sample and $w_{j}$ is a weight associated with country $j$. That is, we summarize credit growth in the rest of the world as the weighted average of domestic credit growth in the remaining $N-1$ countries in the sample. ${ }^{18}$ In this way we obtain a measure that varies both across countries and over time. In what follows, we refer to $\Delta C r e d_{i t}^{*}$ as foreign credit.

Columns (1)-(2) in Table 1 show that foreign credit growth is indeed highly statistically significant in explaining the occurrence of domestic banking crisis, even when controlling for domestic credit growth. This is true both in a simple probabilistic model and in the Logit specification. Therefore, there is information contained in domestic credit growth in the rest of the world that is useful for predicting the occurrence of banking crises at home, even when controlling for the growth of domestic credit. Our simple probabilistic model also allows us to quantify the impact of an increase in foreign credit growth on the probability of a banking crisis at home. ${ }^{19}$ A one standard deviation increase in the five-year average of domestic credit growth increases the probability of a crisis by about 1.6 percentage points, while the equivalent figure for foreign credit growth is approximately 2.2 percentage points. Note that these magnitudes are economically significant, especially taking into account that the sample frequency of crisis in our data set is approximately 3 percent.

We have established that for a given level of domestic credit growth, a banking crisis is more likely to occur at home when foreign credit growth has been high. But while the statistical significance of foreign credit in predicting banking crises at home is informative, it is also important to measure the gains in predictive power of the model as a whole resulting from its inclusion. In the type of models considered, predictive power is measured by the (binary) capacity to distinguish between forthcoming crisis and no-crisis episodes. ${ }^{20}$ In this case, a sensible procedure is to predict that a crisis will happen when the fitted probability

\footnotetext{
${ }^{18}$ We use PPP-adjusted GDP to form weights in the baseline specification, but our findings are robust to using other types of weights (see the robustness exercises in Section 5). Pesaran (2006) shows that — for large values of $N$ - this cross-country weighted average is a simple way to estimate a common factor in our unbalanced panel of credit series.

${ }^{19}$ We do this using the results from the linear probability models rather than from the Logit models as these are easier to interpret. This is because coefficients are not marginal effects in the case of a Logit model, but they need to be converted into them for a given level of the variables they apply to (typically the mean of those variables).

${ }^{20} \mathrm{It}$ is worth noting that this is not a real-time out-of-sample predicting exercise, but rather an in-sample attempt to uncover existing relationships in the data.
} 
Table 1 Banking Crises Prediction - Domestic And Foreign CREDit

\begin{tabular}{|c|c|c|c|c|}
\hline $\begin{array}{l}\text { Specification } \\
\text { Estimation method } \\
\text { Fixed effects }\end{array}$ & $\begin{array}{l}(1) \\
\text { OLS } \\
\text { None }\end{array}$ & $\begin{array}{c}(2) \\
\text { OLS } \\
\text { Country }\end{array}$ & $\begin{array}{l}(3) \\
\text { Logit } \\
\text { None }\end{array}$ & $\begin{array}{c}(4) \\
\text { Logit } \\
\text { Country }\end{array}$ \\
\hline \multicolumn{5}{|l|}{$\Delta$ Cred } \\
\hline Sum of lags & $\begin{array}{l}0.21^{* *} \\
{[0.031]}\end{array}$ & $\begin{array}{l}0.27 * * \\
{[0.014]}\end{array}$ & $\begin{array}{l}7.37 * * \\
{[0.029]}\end{array}$ & $\begin{array}{c}10.66^{* * *} \\
{[0.008]}\end{array}$ \\
\hline \multicolumn{5}{|l|}{$\Delta$ Cred $^{*}$} \\
\hline Sum of lags & $\begin{array}{c}1.44^{* * *} \\
{[0.004]}\end{array}$ & $\begin{array}{c}1.42^{* * *} \\
{[0.006]}\end{array}$ & $\begin{array}{c}48.76^{* * *} \\
{[0.002]}\end{array}$ & $\begin{array}{c}49.71^{* * *} \\
{[0.001]}\end{array}$ \\
\hline Constant & $\begin{array}{c}-0.06^{* *} \\
(0.024)\end{array}$ & $\begin{array}{c}-0.09^{* * *} \\
(0.027)\end{array}$ & $\begin{array}{c}-7.23^{* * *} \\
(1.048)\end{array}$ & $\begin{array}{c}-21.11^{* * *} \\
(1.299)\end{array}$ \\
\hline Observations & 1,118 & 941 & 1,118 & 941 \\
\hline Crises & 34 & 34 & 34 & 34 \\
\hline Test for $C F E$ & & 0.91 & & 1405 \\
\hline p-value & & 0.625 & & 0.000 \\
\hline$R^{2}$ & 0.04 & 0.06 & 0.18 & 0.21 \\
\hline AUROC & 0.80 & 0.84 & 0.81 & 0.83 \\
\hline Standard error & 0.04 & 0.04 & 0.04 & 0.04 \\
\hline
\end{tabular}

Note. Robust standard errors between parentheses, robust-standard-error-based p-values between brackets. $\Delta$ Cred is the growth rate of real lending by domestic banks to domestic households and non-financial corporations, deflated using CPI. For each country and year, $\Delta C r e d^{*}$ is the average of $\Delta C r e d$ for the $N-1$ remaining countries in the sample, weighted by PPP-adjusted GDP. We consider 5 lags of both $\Delta C r e d$ and $\triangle C r e d^{*}$. CFE stands for country fixed effects. AUROC stands for Area Under the Receiving Operating Characteristic curve, a measure of the binary classification ability of the model. Sample covers 38 countries over 1970-2011. The dependent variable is a dummy variable capturing banking crises. See the Appendix for the full set of results (Table B.1).

increases above certain pre-defined threshold.

In terms of measurement, a widely used tool to evaluate the binary classification ability of a model is the Receiving Operating Characteristic (ROC) curve. The ROC curve plots the probability of "true positives" (i.e., the probability of correctly calling a crisis when there is one) in the $\mathrm{y}$-axis against the probability of "false positives" in the $\mathrm{x}$-axis for all possible thresholds for the fitted probability (see Jorda and Taylor, 2011). Figure 4 reports the ROC curves for the different specifications considered above. Specifically, we plot a specification where the independent variable is domestic credit only (Cred); and another one including 
domestic credit and foreign credit $\left(\mathrm{Cred}^{*}\right)$. The interpretation of the ROC curves is simple: a good model will deliver a higher probability of true positives than false positives, leading to points above the 45 -degree line ${ }^{21}$. Ideally, we want a model that approaches high y-values even for low $\mathrm{x}$-values (that is, that has a higher probability of true positives without the cost of a many false positives). ${ }^{22}$

\section{Figure 4 Receiver Operating Characteristic Curves - Comparison Of Different Models}

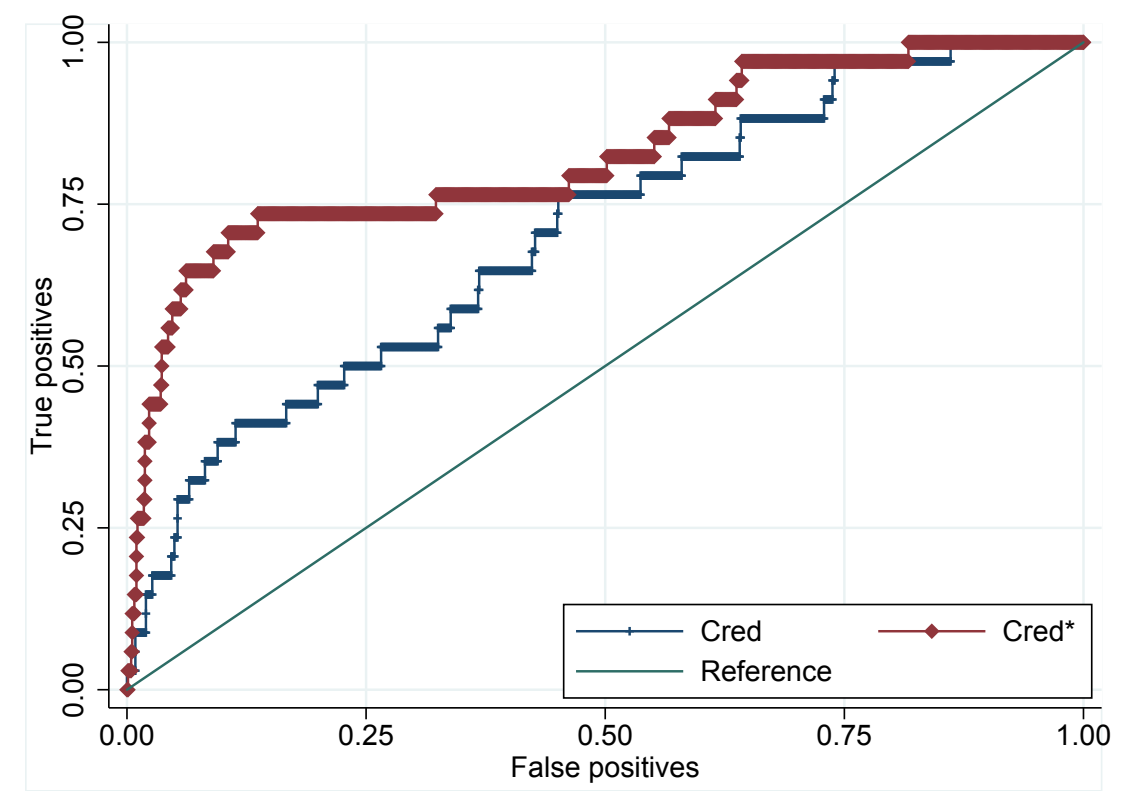

Note. The ROC curve plots the proportion of "true positives" in the yaxis against the proportion of "false positives" in the x-axis for all possible thresholds of the fitted probability. Cred refers to the specification with domestic credit only, and $\mathrm{Cred}^{*}$ refers to the specification with the addition of foreign credit. Both specifications are based on Logit regressions with country fixed effects.

\footnotetext{
${ }^{21}$ Strictly speaking, the relevant benchmark is not the 45 degree line (coin toss) but a specification that only considers country fixed effects. We did that exercise and found that the corresponding ROC curve is significantly below the ones corresponding to our models. Nevertheless, we choose to report the 45 degree line as benchmark for presentational purposes.

${ }^{22}$ If we choose a low threshold (north-east corner of Figure 4), then crises will be called often and there will be many false positives as well as true positives, but few false negatives. In the limit, as the threshold goes to zero, the probability of both true and false positives converges to one (as crises would be called no matter the signal). In contrast, if the threshold is high (south-west corner of Figure 4), we avoid "false alarms" (i.e., calls for crises that will not materialize) but at the cost of missing some actual crises. Again, as the threshold goes to infinity, the probability of having both true and false positives converges to zero (as no crises would be called independently of the signal from the explanatory variables).
} 
Figure 4 shows that all curves lie significantly above the 45-degree line; that is, all variables we consider in our specifications do help the model to distinguish between forthcoming crisis and no-crisis episodes. But Figure 4 also shows that, relative to the specification with domestic credit only, the introduction of foreign credit shifts the ROC curve to the left. That is: foreign credit significantly improves the predictive power of the model vis-a-vis a version that relies on domestic credit growth only.

A commonly used measure for formally comparing the predictive power of different models is the comparison of the area under the ROC curves (AUROC): the steeper the ROC curve, the larger the area under it and the better the binary classification ability of the model. ${ }^{23}$ When testing for the statistical difference between the AUROCs we find that the specification that includes foreign credit has a (statistically significant) larger AUROC than the model with domestic credit only. Note that this is not a direct consequence of the statistical significance of the variables in the regressions: indeed a variable can be statistically significant but lead to only a marginal increase in the classification ability of the model. ${ }^{24}$ In sum, the inclusion of foreign credit growth significantly enhances the ability of our model to distinguish between forthcoming crisis and no-crisis episodes.

\subsection{The Role of Openness}

The baseline specifications in equations (1)-(2) implicitly assume that the impact of foreign credit growth on domestic financial stability is homogeneous across countries. We explore here a potential source of heterogeneity that could configure a first step in uncovering the mechanisms underlying the results reported above. In particular, we are interested in exploring whether the effect of foreign credit growth on the probability of suffering a banking crisis varies across countries/periods with different degrees of openness.

There are at least two relevant dimensions in which a country can be open: it can be open to trade and it can be open to financial transactions with non-residents (which we refer to as financial openness). We explore these two dimensions by interacting proxies of these degrees of openness with measures of foreign credit growth. If these interactions yield positive and significant coefficients, the effect of foreign credit growth on domestic financial stability is

\footnotetext{
${ }^{23}$ Note that it is beyond the scope of our paper to take a particular stance on the preference of policymakers between type I and type II errors (that is, between false positives and false negatives). See Alessi and Detken (2011) for a detailed discussion. In what respects to our exercise, the monotonic increase in ROC curves in most cases means that conclusions are independent of such considerations.

${ }^{24} \mathrm{An}$ analogy can be drawn with variables that are significant but increase the $R^{2}$ of a regression only marginally.
} 
stronger for more open economies.

We begin by exploring the effect of financial openness. The period considered (1970-2011) was one of increasing capital mobility at the global level, with important differences across countries and over time in terms of their financial openness. ${ }^{25}$ Financial openness is not directly observable, and hence needs to be proxied. One possibility is to look at countries' (gross) external liabilities, using the data constructed by Lane and Milesi-Ferretti (2007). The idea behind the proxy is that financially closed countries would, by definition, be less likely to develop substantial gross external liabilities. ${ }^{26}$

In our first experiment we interact this proxy of financial openness with foreign credit growth. The estimation of this specification is reported in columns (1)-(2) of Table 2. The results show that the effect of foreign credit growth is indeed more important for financially open countries. Interestingly, factoring in the degree of financial openness increases the binary classification of the model significantly (there is a large increase in the AUROC). Note that we find similar results if instead of using this proxy we rely on an alternative index proposed by Chinn and Ito (2006). ${ }^{27}$ In fact, when both indexes are considered jointly, both interaction terms are significant. This is not entirely surprising since the indices measure two related but different things: the index based on Lane and Milesi-Ferretti (2007) data reflects the degree of international financial integration, including the extent of controls as well as other determinants of openness, while Chinn and Ito (2006)'s index reflects the number of controls. $^{28}$

When it comes to trade openness, we follow the standard approach of proxying it by computing the sum of exports and imports (normalized by GDP). Of course, a country that is more open to trade would be expected to display higher values of this proxy. Columns (3)-(4) of Table 2 show that foreign credit growth is not more relevant for explaining the occurrence of domestic banking crises in countries that are more open to trade. Although the reduced-form nature of this exercise means it cannot be taken as direct evidence of the channels through which foreign credit growth affects the probability of experiencing domestic banking crises, the results suggest that financial channels could play a more important role than trade channels. In sum, we conclude that there is robust evidence that foreign credit growth contains useful information for the prediction of domestic banking crises over and above that contained in domestic credit growth. This effect seems to be more important for

\footnotetext{
${ }^{25}$ For a long run view of financial openness at the global level see Reinhart and Rogoff (2009).

${ }^{26}$ Note that results are virtually unchanged if we rely on .

${ }^{27}$ Not reported but available from the authors upon request.

${ }^{28}$ These results are not reported here for brevity but are available from the authors upon request.
} 
Table 2 Banking Crisis Prediction - The Role Of Financial And Trade Openness

\begin{tabular}{|c|c|c|c|c|}
\hline $\begin{array}{l}\text { Specification } \\
\text { Estimation method }\end{array}$ & $\begin{array}{l}(1) \\
\text { OLS }\end{array}$ & $\begin{array}{c}(2) \\
\text { Logit }\end{array}$ & $\begin{array}{l}(3) \\
\text { OLS }\end{array}$ & $\begin{array}{c}(4) \\
\text { Logit }\end{array}$ \\
\hline \multicolumn{5}{|l|}{$\Delta$ Cred } \\
\hline Sum of lags & $\begin{array}{l}0.25^{* *} \\
{[0.019]}\end{array}$ & $\begin{array}{c}9.11^{* * *} \\
{[0.008]}\end{array}$ & $\begin{array}{l}0.28^{* *} \\
{[0.013]}\end{array}$ & $\begin{array}{c}12.4^{* * *} \\
{[0.008]}\end{array}$ \\
\hline \multicolumn{5}{|l|}{$\Delta$ Cred $^{*}$} \\
\hline Sum of lags & $\begin{array}{c}-0.16 \\
{[0.766]}\end{array}$ & $\begin{array}{c}-52.2^{* * *} \\
{[0.010]}\end{array}$ & $\begin{array}{c}1.04^{*} \\
{[0.095]}\end{array}$ & $\begin{array}{c}-8.45 \\
{[0.818]}\end{array}$ \\
\hline $\begin{array}{l}\Delta \text { Cred }^{*} \mathrm{x} \text { FinOpen } \\
\quad \text { Sum of lags }\end{array}$ & $\begin{array}{c}1.01^{* * *} \\
{[0.001]}\end{array}$ & $\begin{array}{c}73.36^{* * *} \\
{[0.000]}\end{array}$ & & \\
\hline $\begin{array}{l}\Delta \text { Cred }^{*} \times \text { TradeOpen } \\
\text { Sum of lags }\end{array}$ & & & $\begin{array}{c}0.44 \\
{[0.303]}\end{array}$ & $\begin{array}{c}90.24 \\
{[0.268]}\end{array}$ \\
\hline FinOpen & $\begin{array}{c}-0.05^{* * *} \\
(0.016)\end{array}$ & $\begin{array}{c}-4.85^{* * *} \\
(1.354)\end{array}$ & & \\
\hline TradeOpen & & & $\begin{array}{c}-0.03 \\
(0.036)\end{array}$ & $\begin{array}{c}-8.74 \\
(7.953)\end{array}$ \\
\hline Constant & $\begin{array}{c}-0.01 \\
(0.026)\end{array}$ & $\begin{array}{c}-17.08^{* * *} \\
(1.122)\end{array}$ & $\begin{array}{l}-0.07^{* *} \\
(0.034)\end{array}$ & $\begin{array}{c}-17.04^{* * *} \\
(3.361)\end{array}$ \\
\hline Observations & 1,115 & 941 & 1,110 & 936 \\
\hline Crises & 34 & 34 & 34 & 34 \\
\hline Test for $C F E$ & 0.89 & 14560 & 0.90 & 996.9 \\
\hline p-value & 0.650 & 0.000 & 0.638 & 0.000 \\
\hline$R^{2}$ & 0.10 & 0.40 & 0.06 & 0.29 \\
\hline AUROC & 0.87 & 0.91 & 0.84 & 0.87 \\
\hline Standard error & 0.03 & 0.02 & 0.04 & 0.04 \\
\hline
\end{tabular}

Note. Robust standard errors between parentheses, robust-standard-error-based p-values between brackets. $\Delta$ Cred is the growth rate of real lending by domestic banks to domestic households and non-financial corporations, deflated using CPI. For each country and year, $\Delta \mathrm{Cred}^{*}$ is the average of $\Delta \mathrm{Cred}$ for the $N-1$ remaining countries in the sample, weighted by PPP-adjusted GDP. We consider 5 lags of both $\Delta C r e d$ and $\Delta$ Cred $^{*}$. FinOpen is the first lag of a proxy for financial openness, namely a country's gross external liabilities as a share of GDP. TradeOpen is the first lag of a proxy for trade openness, namely the sum of exports and imports normalized by GDP. All specifications include country fixed effects. CFE stands for country fixed effects. AUROC stands for Area Under the Receiving Operating Characteristic curve, a measure of the binary classification ability of the model. Sample covers 38 countries over 1970-2011. The dependent variable is a dummy variable capturing banking crises. See the Online Appendix for the full set of results. 
financially open countries.

\section{Inspecting the Mechanism}

The previous section established that, conditional on domestic credit growth, foreign credit growth is a powerful predictor of domestic financial crises. It also established that this effect is stronger in more financially open countries, but not for countries that are more open to trade. This suggests that the channel of transmission is financial rather than through the trade of goods and services. Despite this initial insight, the nature of the transmission mechanism remains open. This section of the paper sheds some light on this question by examining the role played by additional controls and provides a tentative assessment of the importance of different channels.

\subsection{Channels of Transmission of Foreign Credit}

The literature suggests that there are (at least) three channels through which foreign credit growth (and global conditions more generally) could affect domestic financial stability.

(i) Cross-border capital flows. The first, and maybe most obvious, channel is related to the presence of cross-border capital flows (see Reinhart and Reinhart, 2009, Mendoza and Terrones, 2014). If foreign banks increase cross-border lending at the same time they increase domestic lending (as captured by our foreign credit growth variable), then domestic agents would get an additional source of credit (see Bruno and Shin, 2015, for example). ${ }^{29}$ This, in turn, could increase the probability of a banking crisis by reducing average creditworthiness or temporarily inflating asset prices. ${ }^{30}$ Additionally, heightened foreign credit growth could also coincide with a more generalized balance sheet expansion of banks and other foreign agents (beyond bank credit), that could take the form of cross-border portfolio flows into the domestic economy. These flows could increase the probability of experiencing a domestic banking crises if they were misallocated, fuelled bubbles or simply reversed in a quick fashion.

\footnotetext{
${ }^{29}$ Note that so far we have only considered domestically originated credit; both $\Delta C r e d$ and $\Delta C r e d^{*}$ only consider domestic credit growth, ignoring cross-border components.

${ }^{30}$ For example, Cesa-Bianchi et al. (2015) find that that exogenous inflows of bank capital can generate significant fluctuations in domestic consumption and asset prices.
} 
(ii) Risk panics/Sentiment. The second channel concerns the existence self-fulfilling risk panics, as suggested by the seminal work of Bacchetta et al. (2012). Risk panics, or more generally shifts in agents' sentiment, could be global phenomena, typically shared among a broad set of countries and assets, and their impact could be unrelated to financial linkages or fundamentals (see Bacchetta and van Wincoop, 2013) and quantitatively important (van Wincoop, 2013). So, even abstracting from the presence of capital flows, there could still be room for "sentiment" in financial markets to be transmitted across-borders. In this case, foreign credit growth could be a reflection of this global sentiment, which could in turn spillover and affect risk aversion of domestic agents, with consequences for domestic financial stability.

(iii) Contagion. The third channel through which foreign credit growth can affect the probability of experiencing a banking crisis at home is contagion. That is, elevated foreign credit predicts banking crises abroad which, in turn, can spill over to the domestic banking system, generating a domestic banking crisis.

In order to explore these three channels, we consider alternative specifications of our baseline regressions augmenting them with: (i) different type of cross-border capital flows; (ii) variables proxying for/affected by attitudes towards risk in international financial markets; and (iii) the occurrence of banking crises abroad.

\subsubsection{Cross-Border Capital Flows}

The first exercise we conduct is to add as an explanatory variable different types of crossborder capital inflows to our baseline regressions. We consider three different types of inflows: (1) from foreign banks into domestic banks, (2) from foreign banks into domestic non-banks, and (3) from non-residents to all sectors in the form of portfolio debt and equity flows. The main intuition is that, if cross-border capital flows were the channel through which foreign credit growth affects the probability of experiencing domestic banking crises, their inclusion in our regressions should render foreign credit growth insignificant, or at least alter the size of its effect and/or its significance. ${ }^{31}$

The results are reported in Table 3. Columns (1)-(4) show that credit from foreign banks into both domestic banks and non-banks does not affect the probability of experiencing a domestic crisis at home. In contrast, elevated portfolio inflows from non-residents do increase

\footnotetext{
${ }^{31}$ Indeed, while this exercise is naturally linked to the relevance of cross-border capital flows as a transmission mechanism, there could also be other channels in place.
} 
Table 3 Banking Crisis Prediction - Cross-border Capital Inflows

\begin{tabular}{|c|c|c|c|c|c|c|}
\hline \multirow[b]{2}{*}{ Specification } & \multicolumn{2}{|c|}{ Bank inflows to non-banks } & \multicolumn{2}{|c|}{ Bank inflows to banks } & \multicolumn{2}{|c|}{ Portfolio inflows } \\
\hline & (1) & $(2)$ & $(3)$ & (4) & $(5)$ & $(6)$ \\
\hline \multicolumn{7}{|l|}{$\Delta$ Cred } \\
\hline Sum of lags & $\begin{array}{c}11.7^{* * *} \\
{[0.000]}\end{array}$ & $\begin{array}{c}11.61^{* * *} \\
{[0.005]}\end{array}$ & $\begin{array}{c}10.68^{* * *} \\
{[0.002]}\end{array}$ & $\begin{array}{c}10.42^{* *} \\
{[0.010]}\end{array}$ & $\begin{array}{c}12.01^{* *} \\
{[0.031]}\end{array}$ & $\begin{array}{l}12.22^{*} \\
{[0.056]}\end{array}$ \\
\hline $\begin{array}{l}\Delta \text { Cred }^{*} \\
\quad \text { Sum of lags }\end{array}$ & & $\begin{array}{c}46.09^{* * *} \\
{[0.008]}\end{array}$ & & $\begin{array}{c}44.95^{* * *} \\
{[0.008]}\end{array}$ & & $\begin{array}{c}45.96^{* *} \\
{[0.037]}\end{array}$ \\
\hline $\begin{array}{l}\Delta X B-C r e d \\
\quad \text { Sum of lags }\end{array}$ & $\begin{array}{c}-0.29 \\
{[0.627]}\end{array}$ & $\begin{array}{c}-0.83 \\
{[0.240]}\end{array}$ & $\begin{array}{c}1.19 \\
{[0.395]}\end{array}$ & $\begin{array}{c}0.89 \\
{[0.490]}\end{array}$ & $\begin{array}{c}36.43^{* * *} \\
{[0.000]}\end{array}$ & $\begin{array}{c}28.39^{* * *} \\
{[0.003]}\end{array}$ \\
\hline Constant & $\begin{array}{c}-17.21^{* * *} \\
(0.409)\end{array}$ & $\begin{array}{c}-21.87^{* * *} \\
(1.458)\end{array}$ & $\begin{array}{c}-17.40^{* * *} \\
(0.683)\end{array}$ & $\begin{array}{c}-22.16^{* * *} \\
(1.614)\end{array}$ & $\begin{array}{c}-20.87^{* * * *} \\
(0.987)\end{array}$ & $\begin{array}{c}-24.82^{* * * *} \\
(2.181)\end{array}$ \\
\hline Observations & 795 & 795 & 795 & 795 & 622 & 622 \\
\hline Crises & 33 & 33 & 33 & 33 & 29 & 29 \\
\hline Test for $C F E$ & 2367 & 1141 & 1884 & 893.2 & 3009 & 2868 \\
\hline p-value & 0.000 & 0.000 & 0.000 & 0.000 & 0.000 & 0.000 \\
\hline$R^{2}$ & 0.08 & 0.2 & 0.09 & 0.21 & 0.19 & 0.32 \\
\hline AUROC & 0.72 & 0.82 & 0.74 & 0.82 & 0.83 & 0.89 \\
\hline Standard error & 0.04 & 0.04 & 0.05 & 0.04 & 0.03 & 0.04 \\
\hline
\end{tabular}

Note. Robust standard errors between parentheses, robust-standard-error-based p-values between brackets. $\Delta$ Cred is the growth rate of real lending by domestic banks to domestic households and non-financial corporations, deflated using CPI. For each country and year, $\Delta$ Cred $^{*}$ is the average of $\Delta$ Cred for the $N-1$ remaining countries in the sample, weighted by PPP-adjusted GDP. XB-Cred are three different type of inflows, depending on the specification (see heading). We consider 5 lags of $\Delta$ Cred, $\Delta$ Cred $^{*}$ and $X B$-Cred. All specifications are based on Logit regressions and include country fixed effects. CFE stands for country fixed effects. AUROC stands for Area Under the Receiving Operating Characteristic curve, a measure of the binary classification ability of the model. Sample covers 38 countries over 1978-2011 (1980-2011 for portfolio flows). The dependent variable is a dummy variable capturing banking crises. See the Online Appendix for the full set of results.

the probability of experiencing a domestic banking crisis, as it is evident from columns (5)(6). Note that foreign credit growth remains significant after controlling for portfolio flows, reported in column (6). However, both the magnitude and significance of its effect decrease with respect to a specification that does not consider portfolio inflows. ${ }^{32}$

At face value, these results suggest that foreign banks' lending to either domestic banks

\footnotetext{
${ }^{32}$ We check this by running our baseline specification on the same sub-sample for which portfolio flows are available. The coefficients (which, as a result, are different from the ones reported in Table 1) are 14.36 and 62.21 on $\Delta C r e d$ and $\Delta C_{r e d}^{*}$, respectively (both of them statistically significant).
} 
or non-banks is not the mechanism by which global credit conditions affect domestic financial stability, except to the extent that this shows up in domestic credit growth. Note that this would be the case if domestic banks fund themselves via foreign banks in order to extend credit domestically. However, we do not find cross-border bank-to-bank credit to matter even if we exclude domestic credit from our baseline specification (see Table B.3 in the Appendix). ${ }^{33}$ In contrast, the role of foreign portfolio flows, which in turn are highly correlated with global attitudes to risk (Fratzscher, 2012), is telling, and we return to this finding below.

\subsubsection{Other Global Variables}

We also explore the relation between our measure of foreign credit growth and other global variables that the recent literature has found to be relevant in affecting (or proxying for) conditions in global financial markets. ${ }^{34}$ These variables are not necessarily linked to a single one of the channels described above, but could in principle affect several of them. For instance, many of these variables reflect (affect) global financial conditions, which could spur shifts in capital flows at the same time they transmit (or reflect transmission of) sentiment across borders.

We consider global variables that can be broadly categorized in four camps. First, we use the VIX index as a proxy for global uncertainty and risk aversion (Rey, 2013, Bekaert and Hoerova, 2014). Second, we consider variables related to the stance of monetary policy in the United States: the level of short-term rates, which has been found to affect the level of risk taking (Borio and Zhu, 2012, Jimenez et al., 2014, Bruno and Shin, 2015); and the slope of the yield curve (as in Cerutti et al., 2014). We also factor in the leverage of US broker-dealers, which is in turn affected both by risk aversion and by the stance of US monetary policy, could also reflect sentiment in global financial markets and is a powerful proxy for 'push' shocks to capital flows (Bruno and Shin, 2015). Finally, we also consider the level of corporate spreads in the US, which reflect corporate funding conditions, investor uncertainty and risk aversion; and has also been found to have predicting power for economic activity measures in the US (Lopez-Salido et al., 2016).

We adopt the simplest possible approach and consider each of the variables mentioned

\footnotetext{
${ }^{33}$ The results from this regression are surprising, since many studies in the literature have found an important role of bank-to-bank credit in affecting domestic credit supply and, more generally, economic activity (e.g. Baskaya et al., 2016, Cesa-Bianchi et al., 2015). We interpret our result as suggesting that, while bank-to-bank credit might be important in explaining business cycle fluctuations, it is not in explaining the occurrence of crises. These results are robust to considering a common sample for which bank and portfolio inflows (and the VIX index) are available.

${ }^{34}$ See, for example, Bruno and Shin (2015) and Cerutti et al. (2014).
} 
Table 4 Banking Crisis Prediction - The Role Of Other Global Variables

\begin{tabular}{|c|c|c|c|c|c|c|}
\hline Specification & (1) & (2) & (3) & (5) & (6) & (7) \\
\hline$\Delta$ Cred & $\begin{array}{c}10.66^{* * *} \\
{[0.008]}\end{array}$ & $\begin{array}{c}13.23^{* * *} \\
{[0.007]}\end{array}$ & $\begin{array}{c}10.7^{*} \\
{[0.050]}\end{array}$ & $\begin{array}{l}9.78^{* *} \\
{[0.032]}\end{array}$ & $\begin{array}{c}11.76^{* *} \\
{[0.022]}\end{array}$ & $\begin{array}{c}11.11^{* *} \\
{[0.017]}\end{array}$ \\
\hline$\Delta$ Cred $^{*}$ & $\begin{array}{c}49.71^{* * *} \\
{[0.001]}\end{array}$ & $\begin{array}{c}89.37 * * * \\
{[0.001]}\end{array}$ & $\begin{array}{c}6.26 \\
{[0.678]}\end{array}$ & $\begin{array}{c}36.79^{* * *} \\
{[0.006]}\end{array}$ & $\begin{array}{c}12.47 \\
{[0.386]}\end{array}$ & $\begin{array}{c}25.95 \\
{[0.168]}\end{array}$ \\
\hline Spread & & $\begin{array}{c}-5.97^{* * *} \\
{[0.000]}\end{array}$ & & & & \\
\hline$r^{S T}$ & & & $\begin{array}{c}-43.73^{* * *} \\
{[0.003]}\end{array}$ & & & \\
\hline Slope & & & & $\begin{array}{c}102.5 \\
{[0.127]}\end{array}$ & & \\
\hline$V I X$ & & & & & $\begin{array}{c}-0.38^{* * *} \\
{[0.000]}\end{array}$ & \\
\hline$L E V$ & & & & & & $\begin{array}{c}21.06^{* * *} \\
{[0.002]}\end{array}$ \\
\hline Constant & $\begin{array}{c}-21.11^{* * *} \\
(1.299)\end{array}$ & $\begin{array}{c}-12.42^{* * *} \\
(2.047)\end{array}$ & $\begin{array}{c}-19.03^{* * *} \\
(1.369)\end{array}$ & $\begin{array}{c}-22.02^{* * *} \\
(1.633)\end{array}$ & $\begin{array}{c}-12.49^{* * *} \\
(1.479)\end{array}$ & $\begin{array}{c}-23.79 * * * \\
(1.262)\end{array}$ \\
\hline Observations & 941 & 941 & 941 & 941 & 772 & 606 \\
\hline Crises & 34 & 34 & 34 & 34 & 32 & 31 \\
\hline Test for $C F E$ & 1405 & 798 & 438 & 1020 & 476 & 56957 \\
\hline $\mathrm{p}$-value & 0.000 & 0.000 & 0.680 & 0.010 & 0.390 & 0.170 \\
\hline$R^{2}$ & 0.21 & 0.35 & 0.33 & 0.31 & 0.39 & 0.39 \\
\hline AUROC & 0.83 & 0.91 & 0.90 & 0.89 & 0.91 & 0.92 \\
\hline Standard error & 0.04 & 0.03 & 0.03 & 0.03 & 0.03 & 0.02 \\
\hline
\end{tabular}

Note Robust standard errors between parentheses, robust-standard-error-based p-values between brackets. $\Delta$ Cred is the growth rate of real lending by domestic banks to domestic households and non-financial corporations, deflated using CPI. For each country and year, $\Delta \mathrm{Cred}^{*}$ is the average of $\Delta$ Cred for the $N-1$ remaining countries in the sample, weighted by PPP-adjusted GDP. Spread is the spread between US Baa-rated corporate bond yields and US Treasury bills. $r^{S T}$ is $\log (1+F F R) / \log (1+\Pi)$, where $F F R$ is the effective Fed funds rate and $\Pi$ is ex-post realised CPI inflation. Slope is $\log \left(1+i^{10 y}\right) / \log (1+F F R)$, where $i^{10 y}$ is the yield of a 10-y maturity Treasury bond in the US, and FFR is defined above. VIX is the CBOE Volatility Index. LEV is (the growth rate in) the leverage of main US broker-dealer banks, taken from Bruno and Shin (2015). All coefficients correspond to the sum of the coefficients attached to the first five lags of each variable. All specifications are based on Logit regressions and include country fixed effects. CFE stands for country fixed effects. AUROC stands for Area Under the Receiving Operating Characteristic curve, a measure of the binary classification ability of the model. Sample covers 38 countries over 1970-2011. The dependent variable is a dummy variable capturing banking crises. Full set of results with individual lags available upon request.

above separately, adding them in turn to our baseline specification that considers domestic and foreign credit growth for the purpose of predicting domestic banking crises. To be 
consistent with our baseline specification with domestic and foreign credit growth only, we consider five lags for each of these global variables.

The results are reported in Table 4. US corporate spreads, the VIX index, US real shortterm interest rates, and the leverage of US broker-dealers are all significant, and all have the expected sign. Specifically, low values of the VIX, of US corporate spreads, and of shortterm rates increase the probability of subsequent banking crises, while the same is true for increases in the leverage of US broker-dealers. We tried including credit growth in the United States (which correlation with global credit is 0.65) as a further global variable but it was not statistically significant. This finding is noteworthy, and we return to its interpretation below. ${ }^{35}$

\subsubsection{Contagion}

The effect of foreign credit growth (and in turn, other foreign variables) on domestic financial stability may be a reflection of these variables generating banking crises abroad, which in turn spill over to the domestic banking system. In order to test for this alternative hypothesis we include an additional variable in our specification that controls for the occurrence of banking crises abroad. ${ }^{36}$

The results (reported in the Appendix in Table B.4 for brevity) show that, although the added variable is significant, foreign credit growth remains significant too. This implies that the effect of foreign credit growth on domestic financial stability goes beyond a direct crisiscontagion mechanism, and that there should be other channels (including the ones described above) through which this effect materializes.

\subsection{Interpretation}

What do these results tell us about the underlying mechanisms that drive our main finding, namely that foreign credit growth portends financial crisis at home? Firstly, and as noted above, the magnifying role played by financial openness suggests that transmission occurs through financial markets rather than the trade of goods and services. Within this, direct crisis contagion appears to play some role, but does not explain the totality of our results,

\footnotetext{
${ }^{35}$ Note that the sample period varies across specifications because of data availability. Results do not display any substantial difference if we consider a sample period that is common to all specifications.

${ }^{36}$ Specifically, we add a GDP-weighted average of dummy variables that take the value of one in case each of the remaining countries in the sample is experiencing a banking crisis.
} 
as foreign credit remains significant even after conditioning on realized foreign crises. Furthermore, in results we do not report here, we find that foreign credit growth weighted by outward banking exposures is not significant when added to our baseline regression (which includes foreign credit weighted by PPP GDP weights). So there is no strong evidence that direct exposure to booming financial systems is the main channel through which high foreign credit growth affects domestic financial stability.

Summarizing the results from the previous section, the global variables that - together with foreign credit - seem to be good predictors of domestic banking crises are the VIX index, US corporate bond spreads, US broker dealers' leverage, US short-term rates, and cross-border portfolio inflows. While many of these indicators relate to conditions in the US financial system, the insignificance of US credit growth in our regressions suggests that they are signals for global rather than US-based risk per se.

Foreign credit growth remains significant even when we control for US corporate bond spreads and portfolio inflows, which are themselves significant. However, in the case of the VIX index, US broker dealers' leverage, and US short-term interest rates, foreign credit is rendered insignificant. This suggests that these variables capture similar dynamics.

Indeed, when analyzing the ROC curves for models where we consider a single global variable at a time (jointly with domestic credit growth), we find that foreign credit growth, the VIX index, broker dealers' leverage, US corporate credit spreads, and US short-term rates have very similar predictive ability in terms of AUROCs (see Figure 5). In fact, AUROCs corresponding to these models are not different statistically, and they are all larger than those corresponding to the other global variables considered (not reported here for presentational purposes, but available from the authors upon request).

In the absence of a structural model, the task of distinguishing the economic mechanisms underlying our results is a difficult one, and the interpretation necessarily speculative. We see this evidence as suggesting that a combination of "push" factors for capital flows and broader changes in global risk sentiment might be the relevant channels at play.

In summary, our results suggest that domestic financial stability is at the mercy of exogenous push shocks and broader swings in global sentiment, which can affect the probability of domestic banking crises over and above their relationship with both domestic credit growth and the realization of banking crises abroad. Global risk sentiment can be captured with variety of price- and quantity-based proxies, of which foreign credit growth is a prominent example. 
Figure 5 Receiver Operating Characteristic Curves Comparison Of Models Using Competing Global VariABLES

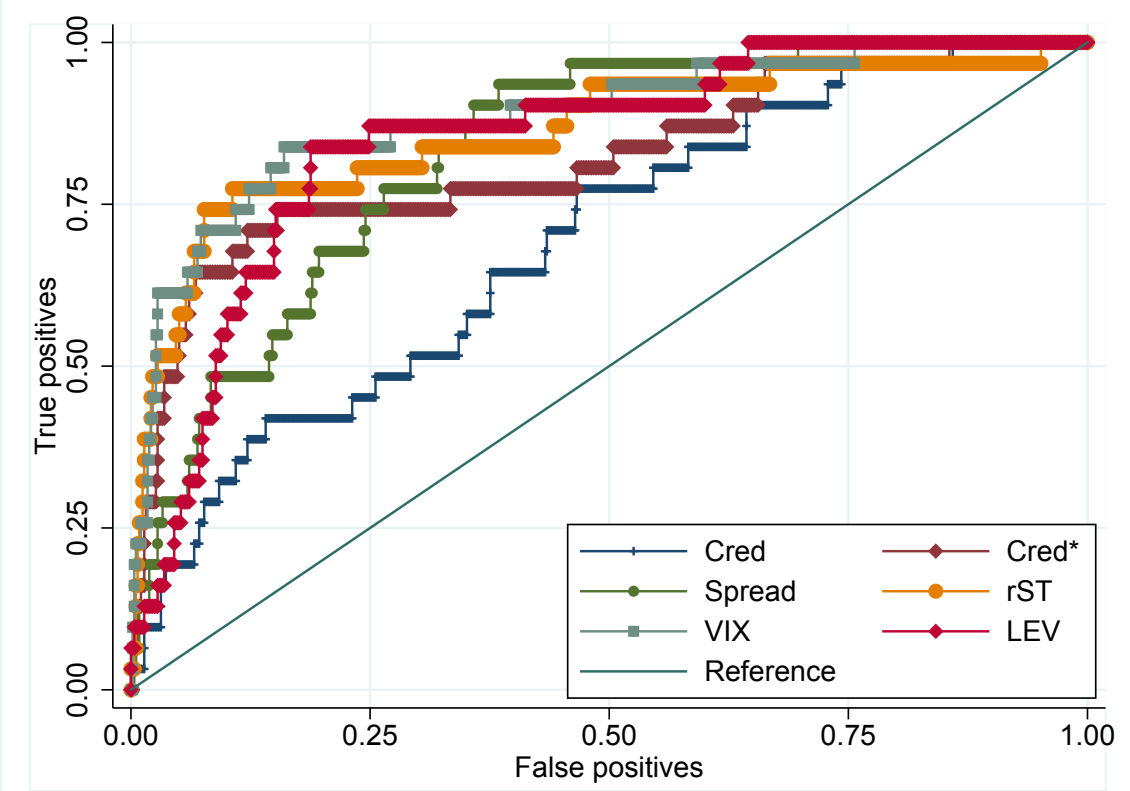

Note. The ROC curve plots the proportion of "true positives" in the yaxis against the proportion of "false positives" in the x-axis for all possible thresholds of the fitted probability. Cred refers to the specification with domestic credit only. $\mathrm{Cred}^{*}$ refers to the specification with the addition of foreign credit to domestic credit growth. Spread, rST, VIX and LEV refer to the specifications with the (alternative) addition of US corporate credit spreads, the (ex-post) real Fed Funds Rate, the VIX index and (changes in) the leverage of US broker dealers to domestic credit growth. All specifications are based on Logit regressions with country fixed effects.

\section{Robustness}

In this section we consider a set of additional specifications that shows the robustness of our results.

Alternative dataset: a historical perspective. The first robustness check that we run is to test whether our results hold in the longer ST's database. As ST note, a sample of exclusively advanced countries tends to be more homogeneous and less plagued by episodes of economic instability that were once typical of emerging markets. On the other hand, the long period considered (1970-2008) means that there can be some additional heterogeneity over time compared to LV/BIS' database.

For this purpose, we proceed in the same way as before and weight credit growth in the 
Table 5 Banking Crisis Prediction - Domestic And Foreign Credit In Schularick And Taylor (2012) Database

\begin{tabular}{lccc}
\hline Specification & $(1)$ & $(2)$ & $(3)$ \\
Estimation method & OLS & Logit & OLS \\
\hline Cred & & & \\
$\quad$ Sum of lags & $0.48^{* * *}$ & $11.32^{* * *}$ & $0.54^{* * *}$ \\
& {$[0.003]$} & {$[0.001]$} & {$[0.001]$} \\
$\Delta$ Cred $^{*}$ & & & \\
$\quad$ Sum of lags & -0.20 & -5.86 & $0.78^{* * *}$ \\
& {$[0.193]$} & {$[0.189]$} & {$[0.003]$} \\
$\Delta$ Cred $^{*}$ x Non-mobile $K$ & & & -0.15 \\
$\quad$ Sum of lags & & & {$[0.750]$} \\
& & & -0.03 \\
Constant & 0.01 & $-4.31^{* * *}$ & $(0.017)$ \\
& $(0.015)$ & $(0.744)$ & \\
\hline Observations & & & 1,272 \\
Crises & 1,272 & 1,272 & 53 \\
Test for CFE & 53 & 53 & 1.07 \\
p-value & 1.00 & 7.78 & 0.385 \\
$R^{2}$ & 0.445 & 0.858 & 0.06 \\
AUROC & 0.03 & 0.08 & 0.83 \\
Standard error & 0.73 & 0.73 & 0.03 \\
\hline
\end{tabular}

Note. Standard errors between parentheses (based on robust standard errors for Logit specifications only as in ST), and p-values between brackets. $\Delta$ Cred is the growth rate in lending by domestic banks to domestic households and non-financial corporations. For each country and year, $\Delta$ Cred $^{*}$ is the average of $\Delta$ Cred for the $N-1$ remaining countries in the sample, weighted by PPP-adjusted GDP. We consider 5 lags of both $\Delta$ Cred and $\Delta$ Cred $^{*}$. Non-mobile $K$ is a dummy variable that takes the value of one between 1945 and 1971, and zero otherwise (note that WWI and WWII years are dropped as they are clear outliers among many dimensions.) All specifications include country fixed effects. $C F E$ stands for country fixed effects. Sample covers 14 advanced countries over 1870-2008. The dependent variable is a dummy variable capturing banking crises. See the Online Appendix for the full set of results.

rest of the world using (PPP-adjusted) GDP weights. Results are reported in columns (1)(2) of Table 5. In contrast with our baseline, Table 5 shows that foreign credit growth does not have an effect on the probability of having a banking crisis at home. Differently, and consistently with ST's main result, domestic credit growth does.

The regression results just described, if taken at face value, could lead to the conclusion that our main results are specific to the sample of countries and period considered in our new 
database. However, it is worth noting that the sample in ST spans a long period from 1870 to 2008, with changing international monetary and financial arrangements. In particular, international capital mobility, a precondition for many of the potential channels discussed above, was not always high over the long sample period under consideration.

It is therefore important to control for this feature of the international monetary and financial system when assessing the impact of foreign credit growth on countries' domestic financial stability. A difficulty lies in that the quantification of international capital mobility is not an easy task, more so when referring to such distant periods as the $19^{\text {th }}$ century. Nevertheless, there seems to be a relatively broad consensus that international capital mobility was particularly low during the Bretton Woods system. ${ }^{37}$

With this in mind, we assess the importance of foreign credit growth for domestic financial stability during periods of high and low capital mobility separately. We do that by simply adding an interacted dummy variable that takes a value of one in periods of low capital mobility. ${ }^{38}$ Column (3) in Table 5 shows that results change drastically when proceeding this way. Foreign credit growth becomes highly significant in explaining the occurrence of domestic banking crisis in periods of high capital mobility, even after controlling for the effect of domestic credit growth. So, the probability of having a banking crisis at home is high in the case of a global credit boom, even when domestic credit is not booming. ${ }^{39}$

In terms of magnitudes, a one standard-deviation increase in the five-year average of domestic credit growth leads to an increase in the probability of a crisis of about 2.9 percent. Interestingly, an equivalent increase in foreign credit has a bigger impact, at 4.1 percent. These magnitudes are economically significant considering that the frequency of crises in the sample is about 4.2 percent, and are also in the same ballpark as those found in Section 3 for our new dataset.

The significant increase in the number of crisis episodes that results from considering ST's database allows us to test whether our main result (that is, the importance of foreign credit growth for predicting the occurrence of domestic banking crises) is robust to the exclusion of the great financial crisis of $2007 / 2008$. It is reassuring to see that this is indeed the case

\footnotetext{
${ }^{37}$ See, for example, Obstfeld and Taylor (1998). The years of WWI and WWII were also characterised by low capital mobility, but they are excluded altoghether from all exercises in line with Schularick and Taylor (2012) given they are clear outliers in terms of many variables of interest.

${ }^{38}$ We do this by interacting a Non-mobile $K$ dummy variable with the growth of foreign credit. This dummy takes the value of one between 1945 and 1971.

${ }^{39}$ There is an increase in the predictive capacity of the model after including global variables (see Figure B.5 in Appendix C), as the ROC curve shifts significantly up. As it is clear from the regression results, this extra predictive power comes from the specification that factors in capital mobility.
} 
(foreign credit comes out as strongly significant in the regressions, not reported here but available from the authors upon request).

Advanced and emerging market economies sub-samples. Having documented the importance of foreign credit growth for predicting the occurrence of domestic banking crises in both LV/BIS and ST databases, and considering the compositional differences between the two, it still remains to be explored whether: (i) foreign credit growth is significant for predicting baking crises in emerging market economies (EMs) and (ii) foreign credit growth is significant for predicting banking crises in a wider (and shorter) advanced economies (AEs) dataset than the one considered by ST.

In order to test for this, we split LV/BIS database into EM and AE countries, and reestimate the main specification for each subsample. ${ }^{40}$ Columns (1)-(2) in Table 6 show that results hold for AEs in LV/BIS database. In fact, there is enough cross-sectional heterogeneity such that more financially open AEs are particularly prone to suffer domestic crises when foreign credit growth is elevated (column (2)). In the case of EMs, we can see in column (3) that foreign credit does not seem to play a role in affecting the probability of experiencing a domestic banking crisis. However, we have to bear in mind that EMs are significantly more financially closed than AEs. For example, the median figure for our main proxy of openness, that is net foreign liabilities as a share of GDP, is 0.50 for EMs and 0.92 for AEs. Column (4) shows that there is not enough cross-sectional heterogeneity within EMs so as to see that foreign credit does affect the probability of experiencing domestic banking crises for those more financially open, although the sign is the correct one and p-values are relatively low (0.11) even if not significant at the usual confidence levels.

Alternative weighting schemes for global variables. An additional robustness exercise is to check that our results hold when using alternative weighting schemes to compute the rate of foreign credit growth. In particular, we consider three alternatives: (i) equal weights for all countries in the rest of the world, and two country-specific weighting schemes: (ii) one based on the external exposures of that country's banking sector, and (iii) another based on the pattern of exports of the country in question. Bilateral data is used for the construction of the weights in the latter two alternatives. ${ }^{41}$

Table B.5 in the Appendix shows that our main results are broadly unchanged; that is, foreign credit growth keeps on having a significant effect on the occurrence of banking crises at

\footnotetext{
${ }^{40}$ We do so following the IMF classification of advanced economies. See Appendix A for a list of the countries labelled as 'advanced'.

${ }^{41}$ Of course in these cases $w_{j}$ in equation (3) becomes $w_{i j}$, e.g. the share of country $i$ 's exports to country $j$ over the total exports of country $i$.
} 
Table 6 Banking Crisis Prediction - Advanced And Emerging MARKET ECONOMIES

\begin{tabular}{lcccc}
\hline \multicolumn{2}{c}{ AEs } & & \multicolumn{2}{c}{ EMs } \\
Specification & $(1)$ & $(2)$ & $(3)$ & $(4)$ \\
\hline$\Delta$ Cred & & & & \\
$\quad$ Sum of lags & $16.59^{* *}$ & $30.34^{*}$ & $8.54^{* * *}$ & $12.22^{* * *}$ \\
& {$[0.018]$} & {$[0.085]$} & {$[0.007]$} & {$[0.005]$} \\
$\Delta$ Cred $^{*}$ & & & & \\
$\quad$ Sum of lags & $114.7^{* * *}$ & -49.97 & -37.61 & $-154.9^{* * *}$ \\
& {$[0.000]$} & {$[0.226]$} & {$[0.117]$} & {$[0.000]$} \\
$\Delta$ Cred $^{*}$ x FinOpen & & & & 112.6 \\
$\quad$ Sum of lags & & $145.6^{* *}$ & & {$[0.115]$} \\
& & {$[0.012]$} & & 1.99 \\
Constant & $-28.13^{* * *}$ & $-17.81^{* * *}$ & -1.70 & $(2.612)$ \\
& $(2.966)$ & $(2.162)$ & $(1.991)$ & \\
& & & & 251 \\
Observations & 690 & 690 & 251 & 12 \\
Crises & 22 & 22 & 12 & 17.98 \\
Test for CFE & 645.3 & 656.9 & 5.51 & 0.035 \\
p-value & 0.000 & 0.000 & 0.788 & 0.26 \\
$R^{2}$ & 0.45 & 0.6 & 0.13 & 0.68 \\
AUROC & 0.68 & 0.75 & 0.52 & 0.05 \\
Standard error & 0.07 & 0.06 & 0.05 & \\
\hline
\end{tabular}

Note. Robust standard errors between parentheses, robust-standard-error-based p-values between brackets. $\Delta C r e d$ is the growth rate of real lending by domestic banks to domestic households and non-financial corporations, deflated using CPI. For each country and year, $\Delta$ Cred $^{*}$ is the average of $\Delta$ Cred for the $N-1$ remaining countries in the sample, weighted by PPP-adjusted GDP. We consider 5 lags of both $\Delta C r e d$ and $\Delta$ Cred $^{*}$. FinOpen is the first lag of a proxy for financial openness, namely a country's gross external liabilities as a share of GDP. All specifications are based on Logit regressions and include country fixed effects. CFE stands for country fixed effects. AUROC stands for Area Under the Receiving Operating Characteristic curve, a measure of the binary classification ability of the model. Sample covers 38 countries (25 advanced and 13 emerging, as classified by the IMF — see the Appendix for the definitions) over 1970-2011. The dependent variable is a dummy variable capturing banking crises. See the Online Appendix for the full set of results.

home despite changing the weighting scheme. The slightly lower AUROCs and $R^{2}$ statistics of the specification which relies on export weights works as further tentative evidence that transmission channels are more likely to be financial rather than real (as suggested when investigating the role of countries' trade and financial openness in Section 3).

Alternative lag structure. Finally, we make sure that results are robust to choosing an 
alternative number of lags of the credit series included in our regressions. In particular, we consider three lags instead of the five considered in the original exercises following ST. Table B.6 in the Appendix reports the results for the estimation which uses the LV/BIS dataset (that is, an analogue of Table 1 which considers three lags). It can be seen that results are broadly unchanged with respect to the baseline specification. That is, the strong effect of foreign credit growth on domestic financial stability is not a function of the number of lags considered in our regressions.

\section{Conclusions}

This paper has shown that global credit growth matters for domestic financial stability, to a similar extent (on average) as domestic credit growth. The channels of transmission are mostly financial, in that foreign variables matter much more in financially open countries but not in countries more open to trade in goods and services. It provides tentative evidence that cross-border portfolio inflows and global attitudes to risk play an important role in domestic financial stability. And it shows that this finding is robust to using different data and to varying the econometric specification.

These findings have at least two important implications for policy institutions charged with monitoring and containing systemic financial stability risks. First, they underline the importance of monitoring global variables when assessing risks to domestic financial stability. And second, they provide prima facie evidence of the spillovers that financial developments in one country can create for others. Such externalities provide a case for international standards for a broader coordination of responses to building financial risks. 


\section{References}

Acharya, V., I. Drechsler, And P. Schnabl (2014): "A Pyrrhic Victory? Bank Bailouts and Sovereign Credit Risk," The Journal of Finance, 69, 2689-2739.

Aikman, D., A. G. Haldane, And B. D. Nelson (2015): "Curbing the Credit Cycle," Economic Journal, 125, 1072-1109.

Alessi, L. And C. Detken (2011): "Quasi real time early warning indicators for costly asset price boom/bust cycles: A role for global liquidity," European Journal of Political Economy, 27, $520-533$.

Bacchetta, P., C. Tille, And E. van Wincoop (2012): "Self-Fulfilling Risk Panics," American Economic Review, 102, 3674-3700.

Bacchetta, P. And E. VAn Wincoop (2013): "Sudden spikes in global risk," Journal of International Economics, 89, 511-521.

Baskaya, Y. S., J. di Giovanni, S. Kalemli-Ozcan, J.-L. Peydro, and M. Fatih Ulu (2016): "Capital Flows and the International Credit Channel," in NBER International Seminar on Macroeconomics 2016, National Bureau of Economic Research, Inc, NBER Chapters.

Bekaert, G. And M. Hoerova (2014): "The VIX, the variance premium and stock market volatility," Journal of Econometrics, 183, 181-192.

Bordo, M., B. Eichengreen, D. Klingebiel, and M. S. Martinez-Peria (2001): "Is the crisis problem growing more severe?" Economic Policy, 16, 51-82.

Borio, C. And M. Drehmann (2009): "Assessing the risk of banking crises - revisited," $B I S$ Quarterly Review.

Borio, C. And P. Lowe (2002a): "Assessing the risk of banking crises," BIS Quarterly Review. (2002b): "Asset prices, financial and monetary stability: exploring the nexus," Tech. rep.

Borio, C. And W. R. White (2003): "Whither monetary and financial stability : the implications of evolving policy regimes," Proceedings - Economic Policy Symposium - Jackson Hole, 131-211.

Borio, C. AND H. ZHU (2012): "Capital regulation, risk-taking and monetary policy: A missing link in the transmission mechanism?" Journal of Financial Stability, 8, 236-251.

Broner, F., T. Didier, A. Erce, And S. L. Schmukler (2013): "Gross capital flows: Dynamics and crises," Journal of Monetary Economics, 60, 113-133.

Bruno, V. And H. S. Shin (2015): "Cross-Border Banking and Global Liquidity," Review of Economic Studies, 82, 535-564.

Caprio, G. J. And D. Klingebiel (1996): "Bank insolvencies : cross-country experience," Policy Research Working Paper Series 1620, The World Bank. 
(2002): "Episodes of systematic and borderline financial crises," in Managing the Real and Fiscal Effects of Banking Crises, Washington, DC: World Bank, 31-49, ed. d klingebiel, l laeven ed.

Cerutti, E. M., S. Claessens, and L. Ratnovski (2014): "Global Liquidity and Drivers of Cross-Border Bank Flows," IMF Working Papers 14/69, International Monetary Fund.

Cesa-Bianchi, A. (2013): "Housing cycles and macroeconomic fluctuations: A global perspective," Journal of International Money and Finance, 37, 215-238.

Cesa-Bianchi, A., L. F. Cespedes, and A. Rebucci (2015): "Global Liquidity, House Prices, and the Macroeconomy: Evidence from Advanced and Emerging Economies," Journal of Money, Credit and Banking, 47, 301-335.

Cesa-Bianchi, A., M. H. Pesaran, and A. Rebucci (2014): "Uncertainty and Economic Activity: A Global Perspective," IDB Publications (Working Papers) 86257, Inter-American Development Bank.

Chinn, M. D. And H. Ito (2006): "What matters for financial development? Capital controls, institutions, and interactions," Journal of Development Economics, 81, 163-192.

Clatessens, S. And N. V. Horen (2014): "The Role of Foreign Banks in Local Credit Booms," in The Future of Large, Internationally Active Banks. World Scientific Studies in International Economics, ed. by D. D. E. Asli Demirg-Kunt and G. G. Kaufman, New Jersey: World Scientific Publishing, vol. 55, 273-292.

Claessens, S., M. A. Kose, And M. E. Terrones (2011): "Financial Cycles: What? How? When?" NBER International Seminar on Macroeconomics, 7, 303 - 344.

Duca, M. L. And T. A. Peltonen (2013): "Assessing systemic risks and predicting systemic events," Journal of Banking ES Finance, 37, 2183 - 2195.

Eichengreen, B. And K. Mitchener (2003): "The Great Depression as a credit boom gone wrong," BIS Working Papers 137, Bank for International Settlements.

Feenstra, R. C., R. Inklaar, and M. P. Timmer (2015): "The Next Generation of the Penn World Table," American Economic Review, 105, 3150-82.

Fisher, I. (1933): "The Debt Deflation Theory of Great Depressions," Econometrica, 1, 337-357.

Frankel, J. A. And A. K. Rose (1996): "Currency crashes in emerging markets: An empirical treatment," Journal of International Economics, 41, 351-366.

Fratzscher, M. (2012): "Capital flows, push versus pull factors and the global financial crisis," Journal of International Economics, 88, 341-356.

Ghosh, A. R., J. D. Ostry, And M. S. Qureshi (2015): "Exchange Rate Management and Crisis Susceptibility: A Reassessment," IMF Economic Review, 63, 238-276.

Gourinchas, P.-O. And M. Obstfeld (2012): "Stories of the Twentieth Century for the TwentyFirst," American Economic Journal: Macroeconomics, 4, 226-65. 
Hirata, H., M. A. Kose, C. Otrok, and M. E. Terrones (2012): "Global House Price Fluctuations: Synchronization and Determinants," in NBER International Seminar on Macroeconomics 2012, National Bureau of Economic Research, Inc, NBER Chapters.

Jimenez, G., S. Ongena, J.-L. Peydro, and J. Saurina (2014): "Hazardous Times for Monetary Policy: What Do Twenty-Three Million Bank Loans Say About the Effects of Monetary Policy on Credit Risk-Taking?" Econometrica, 82, 463-505.

Jorda, O., M. Schularick, And A. M. Taylor (2011): "Financial Crises, Credit Booms, and External Imbalances: 140 Years of Lessons," IMF Economic Review, 59, 340-378.

Jorda, O. AND A. M. TAYLOR (2011): "Performance Evaluation of Zero Net-Investment Strategies," NBER Working Papers 17150, National Bureau of Economic Research, Inc.

Kindleberger, C. (1978): Manias, Panics, and Crashes: A History of Financial Crises, New York: Basic.

Laeven, L. And F. Valencia (2013): "Systemic Banking Crises Database," IMF Economic Review, 61, 225-270.

Lane, P. R. And G. M. Milesi-Ferretti (2007): "The external wealth of nations mark II: Revised and extended estimates of foreign assets and liabilities, 1970-2004," Journal of International Economics, 73, 223-250.

Lopez-Salido, D., J. C. Stein, And E. Zakrajsek (2016): "Credit-Market Sentiment and the Business Cycle," NBER Working Papers 21879, National Bureau of Economic Research, Inc.

Mendoza, E. G. And M. E. Terrones (2014): "An Anatomy of Credit Booms and their Demise," in Capital Mobility and Monetary Policy, ed. by M. F. D., C. E. Raddatz, and C. M. Reinhart, Central Bank of Chile, vol. 18 of Central Banking, Analysis, and Economic Policies Book Series, chap. 6, 165-204.

Minsky, H. (1986): Stabilizing an Unstable Economy, New Haven, CT: Yale Univ. Press.

Obstfeld, M. And A. M. TAYlor (1998): "The Great Depression as a Watershed: International Capital Mobility over the Long Run," in The Defining Moment: The Great Depression and the American Economy in the Twentieth Century, National Bureau of Economic Research, Inc, NBER Chapters, 353-402.

Pesaran, M. H. (2006): "Estimation and Inference in Large Heterogeneous Panels with a Multifactor Error Structure," Econometrica, 74, 967-1012.

Qian, R., C. M. Reinhart, And K. S. Rogoff (2011): "On Graduation from Default, Inflation and Banking Crises: Elusive or Illusion?" in NBER Macroeconomics Annual 2010, Volume 25, National Bureau of Economic Research, Inc, NBER Chapters, 1-36.

Reinhart, C. And V. Reinhart (2009): "Capital Flow Bonanzas: An Encompassing View of the Past and Present," in NBER International Seminar on Macroeconomics 2008, National Bureau of Economic Research, Inc, NBER Chapters, 9-62. 
Reinhart, C. M. and G. L. Kaminsky (1999): "The Twin Crises: The Causes of Banking and Balance-of-Payments Problems," American Economic Review, 89, 473-500.

Reinhart, C. M. And K. S. Rogoff (2009): This Time Is Different: Eight Centuries of Financial Folly, vol. 1 of Economics Books, Princeton University Press.

Rey, H. (2013): "Dilemma not trilemma: the global cycle and monetary policy independence," Proceedings - Economic Policy Symposium - Jackson Hole, 1-2.

Schularick, M. And A. M. Taylor (2012): "Credit Booms Gone Bust: Monetary Policy, Leverage Cycles, and Financial Crises, 1870-2008," American Economic Review, 102, 1029-61.

VAN Wincoop, E. (2013): "International Contagion through Leveraged Financial Institutions," American Economic Journal: Macroeconomics, 5, 152-89.

WitT, G. (2014): "A Simple Distribution for the Sum of Correlated, Exchangeable Binary Data," Communications in Statistics - Theory and Methods, 43, 4265-4280. 


\section{A Appendix. Data}

\section{A.1 Country list}

Schularick and Taylor (2012)'s subset of 14 advanced economies comprises: Australia, Canada, Switzerland, Germany, Denmark, Spain, France, U.K., Italy, Japan, Netherlands, Norway, Sweden and United States.

Our combined dataset (from Laeven and Valencia (2013) and BIS) comprises those 14 countries plus Argentina, Austria, Belgium, Brazil, China, Czech Republic, Finland, Greece, Hong Kong, Hungary, India, Indonesia, Ireland, Korea, Luxembourg, Malaysia, Mexico, Poland, Portugal, Russia, Singapore, South Africa, Thailand and Turkey.

\section{A.2 Definitions, sources and transformations}

- Schularick and Taylor (2012) compile historical data on outstanding domestic currency lending by domestic banks to domestic households and non-financial corporations over 1870-2008 for the 14 AEs specified above. Series are CPI-deflated and growth rates are computed by taking the first difference of natural logarithms. Data come from different sources depending on the country. See Schularick and Taylor (2012) for more details.

- Schularick and Taylor (2012) construct an annual database of financial crisis episodes based on the documentary descriptions in Bordo et al. (2001) and Reinhart and Rogoff (2009). Crises are defined as instances in which the banking sector of a country experiences bank runs and/or increases in default rates accompanied by large capital losses which lead to official intervention, bankruptcy or forced mergers. See Schularick and Taylor (2012) for a series of consistency checks made on the data.

- We use Laeven and Valencia (2013) dataset of banking crises. The authors date banking crises at the annual frequency based on a series of indices, including the occurrence of distress in the banking system (as measured by runs, losses and/or liquidations) and of significant intervention measures in response to losses. For more details, see Laeven and Valencia (2013).

- We use BIS' data on credit to the private non-financial sector from domestic banks (source: BIS via Datastream). This includes both domestically headquartered banks and domestic affiliates of foreign banks. Data are adjusted for seasonality and breaks. We first deflate the series using countries' CPI indices (obtained from Datastream), 
and then we index the real series to equal 100 in 2010Q1. We compute growth rates by first-differencing the natural logarithm of the data.

- We obtain PPP-adjusted GDP data for our countries of interest from the Penn World Table v8.1. See Feenstra et al. (2015).

- We obtain long-run series of PPP-adjusted GDP for our subset of AEs from Angus Maddison's work. Data is available at: http://www.ggdc.net/maddison/oriindex.htm

- We proxy for a country's financial openness by using Lane and Milesi-Ferretti (2007)'s estimates of external liabilities (normalized by GDP). See Lane and Milesi-Ferretti (2007) for more details on the methodology used in the estimation.

- We use BIS international banking statistics (locational data by residence) to compute cross-border lending from foreign banks into a country's banking and non-banking sectors. In particular, to compute inflows into each country we add claims (total positions, all currencies) of the banking systems in the rest of the countries in the dataset against each country of interest. We take this route instead of relying on liabilities data given many missing observations, mostly for EMs, at the beginning of our sample.

- We use IMF's WEO Balance of Payments data to obtain portfolio inflows into the countries of interest. In particular, we look at countries' gross incurrence of liabilities item within the portfolio investment component of the financial account.

- We classify countries as 'advanced' and 'emerging' following IMF's WEO classification. See Table A.1 for a list of the countries under each category.

- In terms of the "global variables" in Table 4, Spread is the spread between US Baarated corporate bond yields and US Treasury bills (as defined in Lopez-Salido et al. (2016). Source: FRED). $r^{S T}$ is $\log (1+F F R) / \log (1+\Pi)$, where $F F R$ is the effective Fed funds rate and $\Pi$ is ex-post realized CPI inflation (source: Datastream). Slope is $\log \left(1+i^{10 y}\right) / \log (1+F F R)$, where $i^{10 y}$ is the yield of a 10-y maturity Treasury bond in the US, and FFR is defined above (source: Datastream). VIX is the CBOE Volatility Index, which has been extrapolated backwards using the realized volatility of US equities as in Cesa-Bianchi et al. (2014). LEV is (the growth rate in) the leverage of main US broker-dealer banks, taken from Bruno and Shin (2015). 


\section{A.3 Data description}

Table A.1 Banking Crisis Episodes By Country (Laeven and Valencia, 2013)

\begin{tabular}{|c|c|c|c|c|c|}
\hline COUNTRY & CRISES & COUNTRY & CRISES & COUNTRY & CRISES \\
\hline Argentina & 1980, 1989, 1995, 2001 & Hong Kong* & & Poland & 1992 \\
\hline Australia* & & Hungary & 1991,2008 & Portugal* & 2008 \\
\hline Austria* & 2008 & India & 1993 & Russia & 1998,2008 \\
\hline Belgium* & 2008 & Indonesia & 1997 & Singapore* & \\
\hline Brazil & 1990, 1994 & Ireland* & 2008 & South Africa & \\
\hline Canada* & & Italy* & 2008 & Spain* & 1977,2008 \\
\hline China, P.R. & 1998 & Japan* & 1997 & Sweden* & 1991,2008 \\
\hline Czech Republic* & 1996 & Korea* & 1997 & Switzerland* & 2008 \\
\hline Denmark* & 2008 & Luxembourg* & 2008 & Thailand & 1983, 1997 \\
\hline Finland* & 1991 & Malaysia & 1997 & Turkey & 1982,2000 \\
\hline France* & 2008 & Mexico & 1981,1994 & United Kingdom* & 2007 \\
\hline Germany* & 2008 & Netherlands* & 2008 & United States* & 1988,2007 \\
\hline Greece* & 2008 & Norway* & 1991 & & \\
\hline
\end{tabular}

Note. Asterisks denote an "advanced economies", as classified by the IMF. Years correspond to the beginning of banking crises episodes, which display varying lengths 
Table A.2 Summary STATistics of Real Growth of DOMESTiC CREDit From Banks TO THE PRIVATE NON-FINANCIAL SECTOR, BIS

\begin{tabular}{|c|c|c|c|c|c|c|}
\hline Country & Mean & $\mathrm{SD}$ & Median & Max & Min & $\mathrm{N}$ \\
\hline ARGENTINA & 2.99 & 29.25 & 10.93 & 43.73 & -83.42 & 30 \\
\hline AUSTRALIA & 7.23 & 4.42 & 6.82 & 17.68 & -0.12 & 45 \\
\hline AUSTRIA & 4.18 & 4.12 & 4.06 & 13.34 & -3.18 & 45 \\
\hline BELGIUM & 2.56 & 5.19 & 3.62 & 13.00 & -10.24 & 45 \\
\hline BRAZIL & 7.46 & 8.21 & 6.83 & 21.39 & -5.28 & 22 \\
\hline CANADA & 6.30 & 6.17 & 6.10 & 21.86 & -7.33 & 45 \\
\hline CHINA & 12.08 & 6.91 & 11.66 & 28.46 & -7.36 & 30 \\
\hline CZECH REPUBLIC & 1.92 & 11.16 & 2.35 & 20.65 & -27.87 & 22 \\
\hline DENMARK & 3.23 & 4.85 & 2.37 & 15.26 & -3.97 & 45 \\
\hline FINLAND & 4.42 & 6.09 & 3.79 & 21.49 & -6.20 & 41 \\
\hline FRANCE & 3.04 & 3.46 & 3.15 & 10.76 & -4.53 & 45 \\
\hline GERMANY & 1.21 & 3.09 & 0.21 & 7.08 & -3.18 & 24 \\
\hline GREECE & 4.47 & 8.28 & 4.14 & 19.89 & -10.23 & 45 \\
\hline HONG KONG & 6.30 & 7.73 & 6.44 & 24.75 & -5.82 & 35 \\
\hline HUNGARY & 0.41 & 13.07 & 0.69 & 22.12 & -25.71 & 26 \\
\hline INDIA & 8.14 & 7.59 & 6.88 & 27.56 & -12.47 & 45 \\
\hline INDONESIA & 8.70 & 17.86 & 11.91 & 32.74 & -78.68 & 39 \\
\hline IRELAND & 4.57 & 11.49 & 3.30 & 29.88 & -26.10 & 44 \\
\hline ITALY & 2.76 & 4.61 & 2.51 & 12.34 & -4.87 & 41 \\
\hline JAPAN & 2.57 & 4.99 & 1.99 & 18.09 & -9.18 & 45 \\
\hline KOREA & 9.72 & 7.85 & 12.33 & 23.18 & -7.12 & 45 \\
\hline LUXEMBOURG & 6.82 & 8.05 & 7.94 & 20.25 & -4.46 & 12 \\
\hline MALAYSIA & 10.72 & 7.74 & 9.52 & 25.27 & -4.46 & 45 \\
\hline MEXICO & 3.38 & 19.90 & 5.69 & 50.37 & -39.21 & 35 \\
\hline NETHERLANDS & 5.00 & 5.06 & 4.11 & 17.32 & -4.64 & 45 \\
\hline NORWAY & 5.40 & 6.34 & 5.39 & 20.80 & -9.29 & 45 \\
\hline POLAND & 8.70 & 8.96 & 7.29 & 28.19 & -6.08 & 23 \\
\hline PORTUGAL & 4.05 & 8.30 & 3.38 & 21.36 & -13.94 & 45 \\
\hline RUSSIAN FEDERATION & 12.39 & 12.94 & 11.47 & 30.85 & -15.24 & 20 \\
\hline SINGAPORE & 8.40 & 6.48 & 9.14 & 25.65 & -3.53 & 45 \\
\hline SOUTH AFRICA & 4.38 & 6.09 & 3.67 & 17.82 & -9.06 & 45 \\
\hline SPAIN & 3.97 & 7.67 & 3.13 & 20.78 & -13.21 & 45 \\
\hline SWEDEN & 3.49 & 5.01 & 3.49 & 15.58 & -10.17 & 45 \\
\hline SWITZERLAND & 2.99 & 3.30 & 2.90 & 10.57 & -5.76 & 45 \\
\hline THAILAND & 8.67 & 9.54 & 8.25 & 25.53 & -14.41 & 45 \\
\hline TURKEY & 12.44 & 21.20 & 15.64 & 59.38 & -32.52 & 26 \\
\hline UNITED KINGDOM & 4.89 & 5.97 & 5.06 & 16.86 & -7.13 & 45 \\
\hline UNITED STATES & 2.45 & 5.00 & 4.37 & 11.32 & -11.77 & 45 \\
\hline Total & 5.44 & 9.72 & 4.91 & 59.38 & -83.42 & 1460 \\
\hline
\end{tabular}

Note. First five columns are in percentage terms. 


\section{B Appendix. Additional Results}

Table B.1 Banking Crises Prediction - Domestic And Foreign Credit

\begin{tabular}{|c|c|c|c|c|}
\hline Specification & (1) & $(2)$ & (3) & (4) \\
\hline Estimation method & OLS & OLS & Logit & Logit \\
\hline Fixed effects & None & Country & None & Country \\
\hline \multirow[t]{2}{*}{ L. $\Delta C r e d$} & -0.02 & -0.00 & -1.50 & -0.85 \\
\hline & $(0.047)$ & $(0.045)$ & $(1.885)$ & $(2.208)$ \\
\hline \multirow[t]{2}{*}{$\mathrm{L} 2 . \Delta$ Cred } & -0.00 & 0.01 & -1.18 & -0.40 \\
\hline & $(0.047)$ & $(0.053)$ & $(2.327)$ & $(2.334)$ \\
\hline \multirow[t]{2}{*}{ L3. $\Delta$ Cred } & $0.15^{* *}$ & $0.17^{* *}$ & $7.37^{* * *}$ & $7.71^{* *}$ \\
\hline & $(0.069)$ & $(0.072)$ & $(2.832)$ & $(3.559)$ \\
\hline \multirow[t]{2}{*}{ L4. $\Delta$ Cred } & 0.07 & 0.08 & 2.39 & 3.09 \\
\hline & $(0.059)$ & $(0.056)$ & $(3.368)$ & $(2.891)$ \\
\hline \multirow[t]{2}{*}{ L5. $\Delta$ Cred } & 0.01 & 0.02 & 0.29 & 1.11 \\
\hline & $(0.113)$ & $(0.108)$ & $(4.246)$ & $(3.469)$ \\
\hline \multirow[t]{2}{*}{ L. $\Delta$ Cred $^{*}$} & $0.56^{* *}$ & $0.56^{* *}$ & $18.63^{* *}$ & $19.43^{* *}$ \\
\hline & $(0.243)$ & $(0.243)$ & $(8.475)$ & $(9.081)$ \\
\hline \multirow[t]{2}{*}{$\mathrm{L} 2 . \Delta$ Cred $^{*}$} & $0.88^{* * *}$ & $0.87^{* * *}$ & $42.20^{* * *}$ & $43.01^{* * *}$ \\
\hline & $(0.210)$ & $(0.214)$ & $(9.883)$ & $(10.547)$ \\
\hline \multirow[t]{2}{*}{ L3. $\Delta$ Cred $^{*}$} & $-0.34^{*}$ & $-0.34^{*}$ & $-27.46^{* * *}$ & $-28.54^{* * *}$ \\
\hline & $(0.179)$ & $(0.180)$ & $(8.190)$ & $(9.084)$ \\
\hline \multirow[t]{2}{*}{ L4. $\Delta$ Cred $^{*}$} & 0.24 & 0.24 & $13.87^{* *}$ & $14.68^{* *}$ \\
\hline & $(0.144)$ & $(0.144)$ & $(6.780)$ & $(6.669)$ \\
\hline \multirow[t]{2}{*}{ L5. $\Delta$ Cred $^{*}$} & 0.11 & 0.10 & 1.51 & 1.13 \\
\hline & $(0.177)$ & $(0.178)$ & $(6.682)$ & $(6.490)$ \\
\hline Constant & $\begin{array}{c}-0.06^{* *} \\
(0.024)\end{array}$ & $\begin{array}{c}-0.09 * * * \\
(0.027)\end{array}$ & $\begin{array}{c}-7.23^{* * *} \\
(1.048)\end{array}$ & $\begin{array}{c}-21.11^{* * *} \\
(1.299)\end{array}$ \\
\hline Observations & 1,118 & 1,118 & 1,118 & 941 \\
\hline Sum of lagged coeffs. of $\Delta C r e d$ & 0.21 & 0.27 & 7.37 & 10.66 \\
\hline Test for sum of lags $=0(p-v a l)$ & 0.031 & 0.014 & 0.029 & 0.008 \\
\hline Sum of lagged coeffs. of $\Delta C r e d^{*}$ & 1.44 & 1.42 & 48.76 & 49.71 \\
\hline Test for sum of lags $=0$ (p-val) & 0.004 & 0.006 & 0.002 & 0.001 \\
\hline Test for CFE & & 0.91 & & 1405 \\
\hline p-value & & 0.63 & & 0.00 \\
\hline$R^{2}$ & 0.04 & 0.06 & 0.18 & 0.21 \\
\hline AUROC & 0.80 & 0.84 & 0.81 & 0.83 \\
\hline Standard error & 0.04 & 0.04 & 0.04 & 0.04 \\
\hline
\end{tabular}

Note. Robust standard errors between parentheses. $\Delta$ Cred is the growth rate of real lending by domestic banks to domestic households and non-financial corporations, deflated using CPI. For each country and year, $\Delta$ Cred $^{*}$ is the average of $\Delta C r e d$ for the $N-1$ remaining countries in the sample, weighted by PPP-adjusted GDP. We consider 5 lags (L1 to L5) of both $\Delta C r e d$ and $\Delta C_{r e d}{ }^{*}$. CFE stands for country fixed effects. AUROC stands for Area Under the Receiving Operating Characteristic curve, a measure of the binary classification ability of the model. Sample covers 38 countries over 1970-2011. The dependent variable is a dummy variable capturing banking crises. 
Table B.2 Schularick and Taylor (2012) Replication Using LV/BiS Database

\begin{tabular}{|c|c|c|c|c|c|}
\hline Specification & (1) & $(2)$ & $(3)$ & $(4)$ & $(5)$ \\
\hline Estimation method & OLS & OLS & OLS & Logit & Logit \\
\hline Fixed effects & None & Country & Country + year & None & Country \\
\hline \multirow[t]{2}{*}{ L. $\Delta$ Cred } & 0.01 & 0.03 & -0.04 & 0.04 & 0.74 \\
\hline & $(0.062)$ & $(0.064)$ & $(0.062)$ & $(1.543)$ & $(1.783)$ \\
\hline \multirow[t]{2}{*}{$\mathrm{L} 2 . \Delta$ Cred } & 0.05 & 0.06 & -0.01 & 1.26 & 2.03 \\
\hline & $(0.067)$ & $(0.068)$ & $(0.066)$ & $(1.652)$ & $(1.743)$ \\
\hline \multirow[t]{2}{*}{$\mathrm{L} 3 . \Delta C r e d$} & $0.13^{* *}$ & $0.14^{* *}$ & $0.14^{* *}$ & $4.92^{* *}$ & $5.83^{* *}$ \\
\hline & $(0.064)$ & $(0.065)$ & $(0.063)$ & $(2.156)$ & $(2.663)$ \\
\hline \multirow[t]{2}{*}{ L4. $\Delta$ Cred } & 0.07 & 0.08 & 0.06 & 1.96 & $2.36^{*}$ \\
\hline & $(0.061)$ & $(0.062)$ & $(0.059)$ & $(1.917)$ & $(1.420)$ \\
\hline \multirow[t]{2}{*}{$\mathrm{L} 5 . \Delta$ Cred } & -0.02 & 0.00 & 0.03 & -0.30 & 0.61 \\
\hline & $(0.055)$ & $(0.057)$ & $(0.054)$ & $(2.204)$ & $(1.702)$ \\
\hline \multirow[t]{2}{*}{ Constant } & $0.02^{* *}$ & -0.03 & -0.04 & $-4.11^{* * *}$ & $-18.93^{* * *}$ \\
\hline & $(0.007)$ & $(0.030)$ & $(0.043)$ & $(0.289)$ & $(0.568)$ \\
\hline Observations & 1,118 & 1,118 & 1,118 & 1,118 & 941 \\
\hline Sum of lagged coeffs. of $\Delta C r e d$ & 0.24 & 0.32 & 0.19 & 7.88 & 11.57 \\
\hline Test for sum of lags $=0(p-v a l)$ & 0.004 & 0.001 & 0.036 & 0.003 & 0.001 \\
\hline Test for CFE & & 0.52 & 0.50 & & 1067 \\
\hline p-value & & 0.993 & 0.995 & & 0.000 \\
\hline Test for TFE & & & 7.21 & & \\
\hline p-value & & & 0.000 & & \\
\hline$R^{2}$ & 0.01 & 0.03 & 0.22 & 0.04 & 0.08 \\
\hline AUROC & 0.67 & 0.75 & 0.95 & 0.67 & 0.71 \\
\hline Standard error & 0.05 & 0.04 & 0.01 & 0.05 & 0.04 \\
\hline
\end{tabular}

Note. Standard errors between parenthesis (robust standard errors for Logit specifications only as in ST). $\Delta$ Cred is the growth in real lending by domestic banks to domestic households and non-financial corporations, deflated using CPI. CFE and TFE stand for country and time fixed effects, respectively. Sample covers 38 countries over 1970-2011. The dependent variable is a dummy variable capturing banking crises. 
Table B.3 BANKING CRISIS PREDICTION - BANK TO BANK INFLOWS

\begin{tabular}{lcccc}
\hline Specification & $(1)$ & $(2)$ & $(3)$ & $(4)$ \\
$\begin{array}{l}\text { Estimation method } \\
\text { Fixed effects }\end{array}$ & OLS & $\begin{array}{c}\text { OLS } \\
\text { Country }\end{array}$ & $\begin{array}{c}\text { Logit } \\
\text { None }\end{array}$ & $\begin{array}{c}\text { Logit } \\
\text { Country }\end{array}$ \\
\hline $\begin{array}{l}\text { N Cross-border inflows } \\
\quad \text { Sum of lag coeffs }\end{array}$ & 0.04 & $0.05^{*}$ & 0.61 & 1.13 \\
& {$[0.142]$} & {$[0.072]$} & {$[0.177]$} & {$[0.163]$} \\
& & & & \\
Constant & $0.03^{* * *}$ & $-0.02^{*}$ & $-3.41^{* * *}$ & $-18.64^{* * *}$ \\
& $(0.007)$ & $(0.009)$ & $(0.194)$ & $(1.542)$ \\
& & & & \\
\hline Observations & 1,102 & 1,102 & 1,102 & 986 \\
Crises & 41 & 41 & 41 & 41 \\
Test for CFE & & 1.11 & & 307.20 \\
p-value & & 0.298 & & 0.000 \\
$R^{2}$ & 0.00 & 0.02 & 0.01 & 0.04 \\
AUROC & 0.64 & 0.72 & 0.64 & 0.68 \\
Standard error & 0.05 & 0.04 & 0.05 & 0.04 \\
\hline
\end{tabular}

Note. Robust standard errors between parentheses, robust-standard-error-based p-values between brackets. Cross-border inflows are capital inflows from foreign banks into the domestic banking sector. Five lags are considered.CFE stands for country fixed effects. AUROC stands for Area Under the Receiving Operating Characteristic curve, a measure of the binary classification ability of the model. Sample covers 38 countries over 1970-2011. The dependent variable is a dummy variable capturing banking crises. See Online Appendix for full table. 
Table B.4 BANKING CRISIS PREDICTION - CONTROLling FOR FOREIGN CRISES

\begin{tabular}{|c|c|c|c|c|}
\hline $\begin{array}{l}\text { Specification } \\
\text { Estimation method }\end{array}$ & $\begin{array}{l}(1) \\
\text { OLS }\end{array}$ & $\begin{array}{c}(2) \\
\text { Logit }\end{array}$ & $\begin{array}{l}(3) \\
\text { OLS }\end{array}$ & $\begin{array}{c}(4) \\
\text { Logit }\end{array}$ \\
\hline \multicolumn{5}{|l|}{$\Delta C r e d$} \\
\hline Sum of lags & $\begin{array}{l}0.25^{* *} \\
{[0.020]}\end{array}$ & $\begin{array}{c}10.3^{* * *} \\
{[0.006]}\end{array}$ & $\begin{array}{l}0.24^{* *} \\
{[0.024]}\end{array}$ & $\begin{array}{c}9.08^{* * *} \\
{[0.008]}\end{array}$ \\
\hline \multicolumn{5}{|l|}{$\Delta$ Cred $^{*}$} \\
\hline Sum of lags & $\begin{array}{c}0.87^{*} \\
{[0.054]}\end{array}$ & $\begin{array}{l}30.65^{*} \\
{[0.062]}\end{array}$ & $\begin{array}{c}-0.49 \\
{[0.362]}\end{array}$ & $\begin{array}{c}-52.55^{* *} \\
{[0.019]}\end{array}$ \\
\hline $\begin{array}{c}\Delta \text { Cred }^{*} \text { x FinOpen } \\
\text { Sum of lags }\end{array}$ & & & $\begin{array}{c}0.92^{* * *} \\
{[0.002]}\end{array}$ & $\begin{array}{c}72.79 * * * \\
{[0.001]}\end{array}$ \\
\hline FinOpen & & & $\begin{array}{c}-0.05^{* * *} \\
(0.015)\end{array}$ & $\begin{array}{c}-4.81^{* * *} \\
(1.644)\end{array}$ \\
\hline Crisis* & $\begin{array}{c}0.33^{* * *} \\
(0.094)\end{array}$ & $\begin{array}{c}5.42^{* * *} \\
(1.839)\end{array}$ & $\begin{array}{c}0.26^{* * *} \\
(0.084)\end{array}$ & $\begin{array}{c}0.25 \\
(3.425)\end{array}$ \\
\hline Constant & $\begin{array}{c}-0.07 * * * \\
(0.025)\end{array}$ & $\begin{array}{c}-20.38^{* * *} \\
(1.242)\end{array}$ & $\begin{array}{c}-0.01 \\
(0.026)\end{array}$ & $\begin{array}{c}-17.06^{* * *} \\
(1.522)\end{array}$ \\
\hline Observations & 1,118 & 941 & 1,115 & 941 \\
\hline Crises & 34 & 34 & 34 & 34 \\
\hline Test for CFE & 0.91 & 119 & 0.88 & 475.5 \\
\hline p-value & 0.633 & 0.000 & 0.672 & 0.000 \\
\hline$R^{2}$ & 0.08 & 0.23 & 0.11 & 0.40 \\
\hline AUROC & 0.87 & 0.84 & 0.88 & 0.92 \\
\hline Standard error & 0.03 & 0.04 & 0.03 & 0.02 \\
\hline
\end{tabular}

Note. Robust standard errors between parentheses, robust-standard-error-based p-values between brackets. $\Delta$ Cred is the growth rate of real lending by domestic banks to domestic households and non-financial corporations, deflated using CPI. For each country and year, $\Delta$ Cred $^{*}$ is the average of $\Delta C r e d$ for the $N-1$ remaining countries in the sample, weighted by PPP-adjusted GDP. We consider 5 lags of both $\Delta$ Cred and $\Delta$ Cred $^{*}$. FinOpen is the first lag of a proxy for financial openness, namely a country's gross external liabilities as a share of GDP. Crisis* is the weighted average of banking crises taking place at time $t$ in the $N-1$ remaining countries in the sample, weighted by PPP-adjusted GDP. All specifications include country fixed effects. CFE stands for country fixed effects. AUROC stands for Area Under the Receiving Operating Characteristic curve, a measure of the binary classification ability of the model. Sample covers 38 countries over 1970-2011. The dependent variable is a dummy variable capturing banking crises. See Online Appendix for full table. 
Table B.5 BANKING CRISIS PREDICTION - AlteRnAtive WEIGHTING SCHEMES

\begin{tabular}{lcccccc}
\hline Specification & $(1)$ & $(2)$ & $(3)$ & $(4)$ & $(5)$ & $(6)$ \\
\hline Estimation method & OLS & Logit & OLS & Logit & OLS & Logit \\
\hline Weighting method & \multicolumn{2}{c}{ Equal } & Banking exposures & Exports \\
\cline { 2 - 7 }$\Delta$ Cred & $0.23^{* *}$ & $9.55^{* *}$ & $0.33^{* *}$ & $13.74^{* * *}$ & $0.3^{* *}$ & $10.6^{* * *}$ \\
$\quad$ Sum of lag coeffs & {$[0.036]$} & {$[0.011]$} & {$[0.027]$} & {$[0.002]$} & {$[0.012]$} & {$[0.008]$} \\
& & & & & & \\
$\Delta$ Cred $^{*}$ & $1.58^{* * *}$ & $50.53^{* * *}$ & $0.68^{* *}$ & $28.41^{* * *}$ & $0.65^{*}$ & $22.51^{* *}$ \\
$\quad$ Sum of lag coeffs & {$[0.002]$} & {$[0.002]$} & {$[0.042]$} & {$[0.007]$} & {$[0.070]$} & {$[0.020]$} \\
& & & & & & \\
Constant & & & & & & \\
& $-0.11^{* * *}$ & $-21.38^{* * *}$ & $-0.06^{* * *}$ & $-21.72^{* * *}$ & $-0.06^{* * *}$ & $-20.62^{* * *}$ \\
& $(0.030)$ & $(1.439)$ & $(0.017)$ & $(1.313)$ & $(0.019)$ & $(0.584)$ \\
Observations & 1,118 & 941 & 913 & 799 & 1,065 & 915 \\
Test for CFE & 0.87 & 1161 & 0.89 & 880.4 & 0.90 & 37620 \\
p-value & 0.688 & 0.000 & 0.634 & 0.000 & 0.635 & 0.000 \\
$R^{2}$ & 0.06 & 0.21 & 0.04 & 0.16 & 0.04 & 0.14 \\
AUROC & 0.84 & 0.83 & 0.84 & 0.83 & 0.83 & 0.81 \\
Standard error & 0.04 & 0.04 & 0.04 & 0.04 & 0.03 & 0.04 \\
\hline
\end{tabular}

NotE. Robust standard errors between parentheses, robust-standard-error-based p-values between brackets. $\Delta$ Cred is the growth rate of real lending by domestic banks to domestic households and non-financial corporations, deflated using CPI. For each country and year, $\Delta C r e d^{*}$ is the average of $\Delta C r e d$ for the $N-1$ remaining countries in the sample, alternatively weighted by equal weights, weights based on a country's banking sector bilateral exposures to other countries in the sample, and on a country's exports to other countries in the sample. We consider 5 lags of both $\triangle C r e d$ and $\triangle C r e d^{*}$. All specifications include country fixed effects. $C F E$ stands for country fixed effects. AUROC stands for Area Under the Receiving Operating Characteristic curve, a measure of the binary classification ability of the model. Sample covers 38 countries over 1970-2011. The dependent variable is a dummy variable capturing banking crises. See Online Appendix for full table 
Table B.6 BAnking CRISIS PREDiCtion - Alternative LAG StrucTURE

\begin{tabular}{lcccc}
\hline Specification & $(1)$ & $(2)$ & $(3)$ & $(4)$ \\
Estimation method & OLS & Logit & OLS & Logit \\
\hline$\Delta$ Cred & & & & \\
$\quad$ Sum of lag coeffs & 0.14 & 4.75 & 0.12 & 2.78 \\
& {$[0.122]$} & {$[0.151]$} & {$[0.187]$} & {$[0.300]$} \\
$\Delta$ Cred $^{*}$ & & & & \\
$\quad$ Sum of lag coeffs & $1.07^{* * *}$ & $34.99^{* * *}$ & -0.17 & $-43.18^{* * *}$ \\
& {$[0.005]$} & {$[0.001]$} & {$[0.668]$} & {$[0.001]$} \\
& & & & \\
$\Delta$ Cred $^{*}$ x FinOpen & & & $0.81^{* * *}$ & $65.47^{* * *}$ \\
$\quad$ Sum of lag coeffs & & & {$[0.002]$} & {$[0.000]$} \\
& & & $-0.04^{* * *}$ & $-4.19^{* * *}$ \\
FinOpen & & & $(0.012)$ & $(1.095)$ \\
& & & -0.01 & $-15.59^{* * *}$ \\
Constant & $-0.06^{* * *}$ & $-20.08^{* * *}$ & $(0.019)$ & $(0.786)$ \\
& & & & \\
\hline Observations & 1,194 & 1,006 & 1,189 & 1,001 \\
Test for CFE & 0.95 & 2406 & 0.96 & 1356 \\
p-value & 0.563 & 0.000 & 0.538 & 0.000 \\
$R^{2}$ & 0.05 & 0.17 & 0.09 & 0.36 \\
AUROC & 0.82 & 0.81 & 0.87 & 0.89 \\
Standard error & 0.04 & 0.04 & 0.03 & 0.03 \\
\hline
\end{tabular}

Note. Robust standard errors between parentheses, robust-standard-error-based p-values between brackets. $\Delta$ Cred is the growth rate of real lending by domestic banks to domestic households and non-financial corporations, deflated using CPI. For each country and year, $\Delta \mathrm{Cred}^{*}$ is the average of $\Delta \mathrm{Cred}$ for the $N-1$ remaining countries in the sample, weighted by PPP-adjusted GDP. We consider 3 lags of both $\Delta C r e d$ and $\Delta$ Cred $^{*}$ (instead of the 5 lags considered in the main specification). FinOpen is the lag of a proxy for financial openness, namely a country's gross external liabilities as a share of GDP. All specifications include country fixed effects. CFE stands for country fixed effects. AUROC stands for Area Under the Receiving Operating Characteristic curve, a measure of the binary classification ability of the model. Sample covers 38 countries over 1970-2011. The dependent variable is a dummy variable capturing banking crises. See Online Appendix for full table. 
Figure B.1 Empirical And Predicted Frequency Of Banking Crises In ST Data Set Excluding The Global FinanCIAL CRisis Years

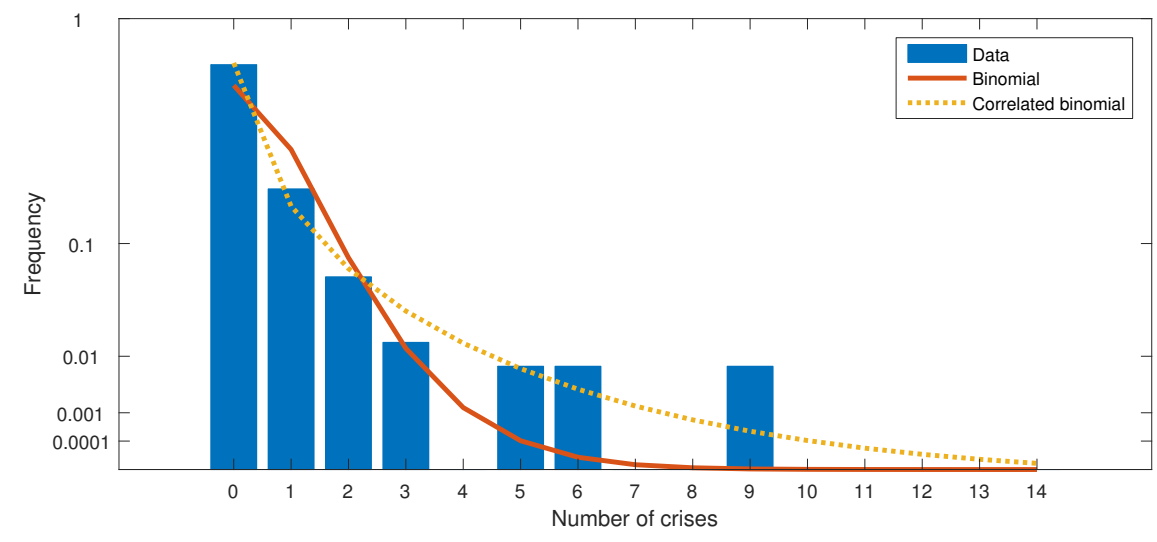

Note. Proportion of countries with (the start of) systemic banking crises in the data (solid line), predicted by a standard binomial distribution (dashed line), and predicted by a correlated binomial distribution (dotted line). The data used is the original data from ST, excluding the Global Financial Crisis years.

Figure B.2 International Synchronization Of Credit Growth - SCREe Plot

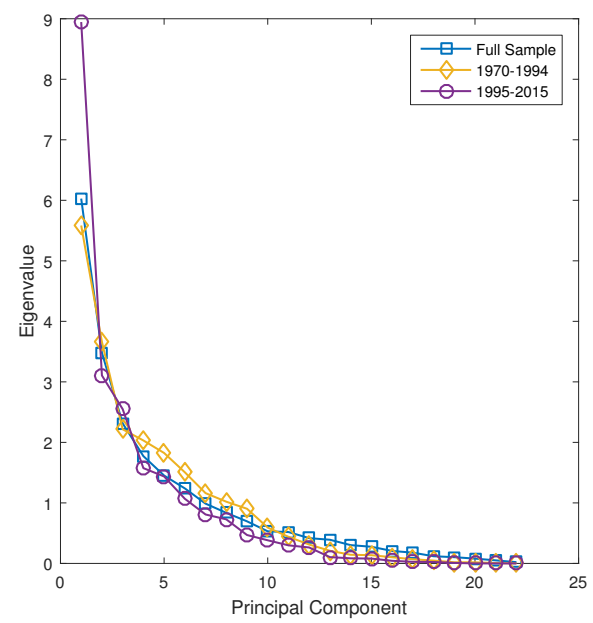

NotE. Eigenvalues associated with the principal components computed on the panel of credit growth series. Squares, diamonds, and circles display the scree plot computed using the full sample, the 1970-1994 sample, and the 1995-2015 sample, respectively. 
Figure B.3 International Synchronization Of Credit Growth Excluding the Global Financial Crisis

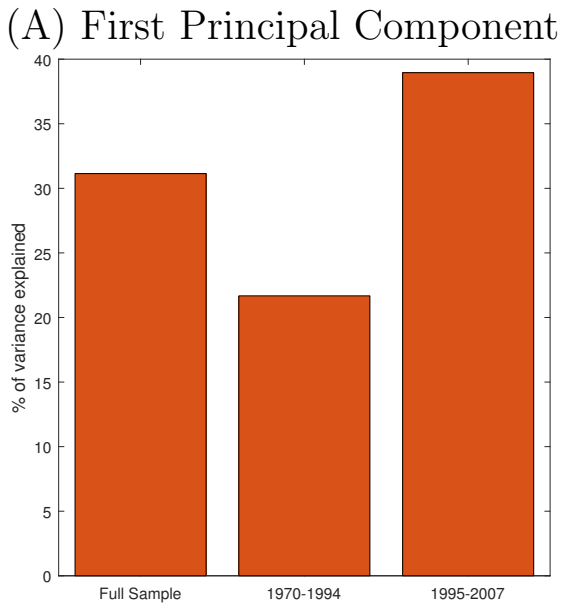

(B) Average Correlation

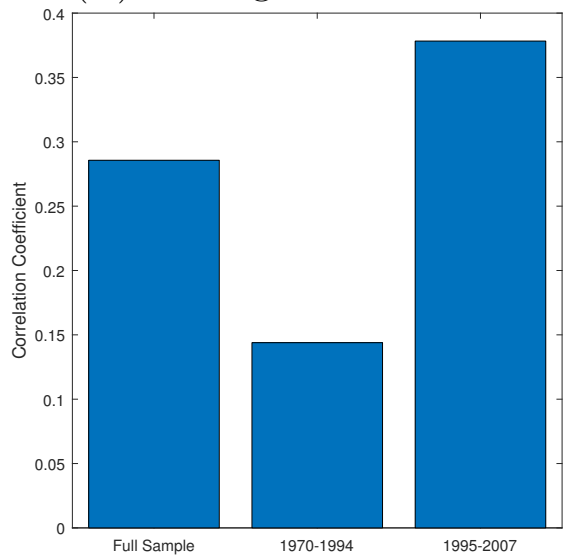

Note. Panel A reports the share of the variance of real domestic credit growth explained by the first principal component, obtained using the same sample of 22 countries as in the main text. Panel B reports the crosscountry average of the correlation between country $i$ 's credit growth and credit growth in the rest of the world, computed as the weighted average of credit growth the remaining $N-1$ countries (where $N=38$ ) over the the sample. The sample period used to produce this charts is 1970-2007, and therefore excludes the global financial crisis.

Figure B.4 International Synchronization Of Credit Growth - Average Correlation in ST database

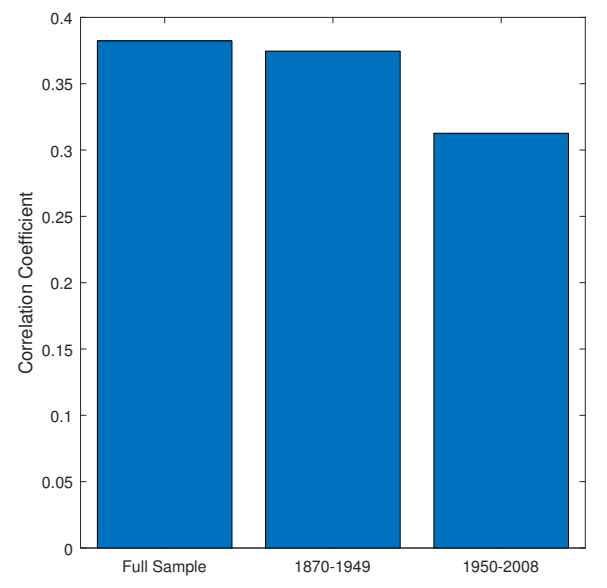

Note. Cross-country average of the correlation between country $i$ 's credit growth and credit growth in the rest of the world, computed as the weighted average of credit growth in the remaining $N-1$ countries (where $N=14$ ) over the sample considered. 
Figure B.5 Receiver Operating Characteristic Curves, ST DATA

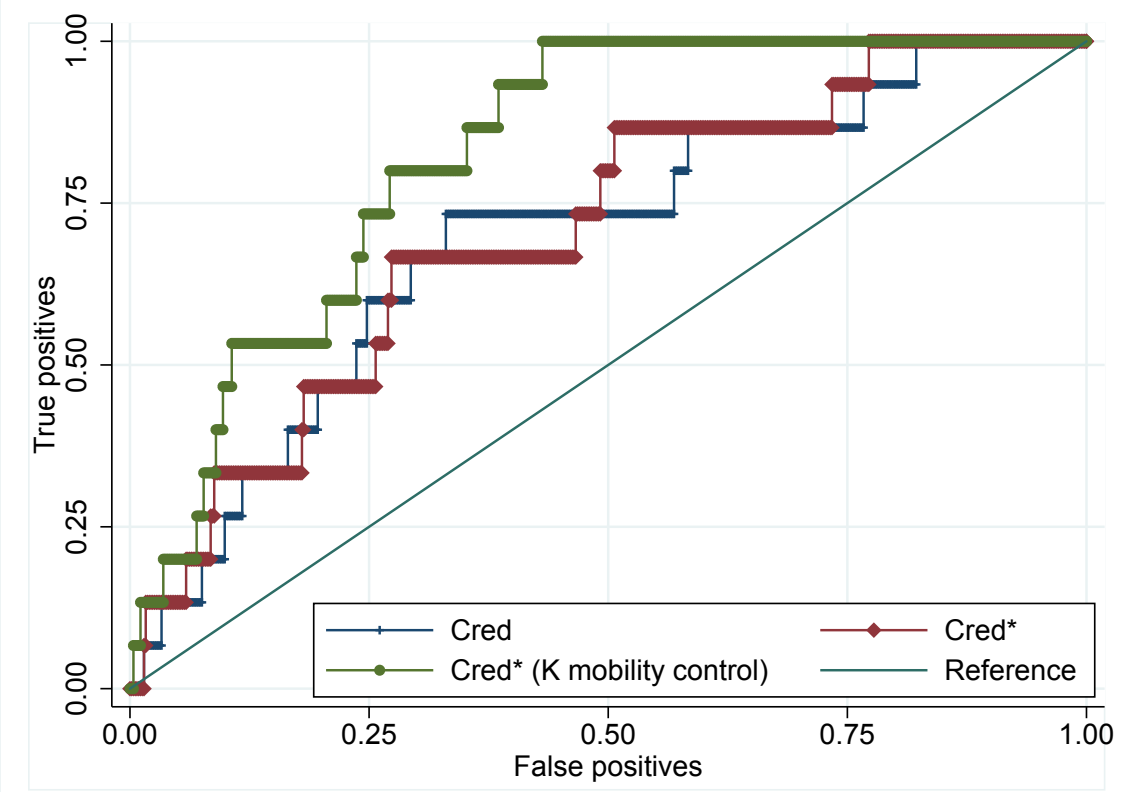

Note. The ROC curve plots the proportion of "true positives" in the yaxis against the proportion of "false positives" in the $\mathrm{x}$-axis for all possible thresholds of the fitted probability. Cred refers to the specification with domestic credit only. Cred* refers to the specification with the addition of foreign credit to domestic credit growth. $\mathrm{Cred}^{*}(K$ mobility control) refers to the specification which adds (interacted) dummy variables during the era of low capital mobility of 1945-1971. All specifications are based on linear regressions with country fixed effects. 